\title{
Structure and dynamics of epifaunal assemblages on intertidal macroalgae Ascophyllum nodosum and Fucus vesiculosus in Nova Scotia, Canada
}

\author{
S. C. Johnson \& R. E. Scheibling \\ Department of Biology, Dalhousie University, Halifax, Nova Scotia B3H 4J1, Canada
}

\begin{abstract}
Abundance and species composition of epifauna on Ascophyllum nodosum and Fucus vesiculosus on a rocky shore in Nova Scotia show pronounced seasonal variation. Total density of epifauna declined by 2 orders of magnitude between summer and winter. Harpacticoid copepods and their nauplii, nematodes, and halacarid mites were numerically the most important components of the assemblage throughout the 13 mo study (May 1983 to Jun 1984). Density was positively correlated with epiphytic algal biomass for most epifaunal taxa. Cluster analysis and multidimensional scaling also indicate that epifaunal sample groupings were strongly related to epiphyte biomass. There was a greater tendency for samples to cluster according to the 2 macroalgal species during the winter, when epiphyte biomass was low, suggesting that epiphytes obscure differences in morphology and/or microbial surface films between $A$. nodosum and $F$. vesiculosus.
\end{abstract}

\section{INTRODUCTION}

A number of studies have documented seasonal fluctuations in epifaunal assemblages on marine benthic macroalgae (see review in Hicks 1985). In general, these studies have been limited to either meiofaunal or macrofaunal size classes or specific taxa. Few studies have investigated the entire epifaunal assemblage. Temporal and spatial variability in epifaunal assemblages or specific taxa on macroalgae have been attributed to a variety of abiotic and biotic factors, e.g. temperature (Hagerman 1966, Gunnill 1983), dessication (Colman 1940), tidal exposure (Gunnill 1983), physiological or growth state of the plant (Hagerman 1966, Mukai 1971, Gunnill 1983, Trotter \& Webster 1983), abundance of epiphytic algae (Colman 1940, Wieser 1959, Hagerman 1966, Zavodnik 1967, Nagel 1968, Kito 1977, Kangas 1978, Edgar 1983, Gunnill 1983), abundance of specific microorganisms (Trotter \& Webster 1983), predation (Hagerman 1966, Edgar 1983), and intra and interspecific competition (Hagerman 1966, Hicks 1977c, Hicks 1980).

Members of the family Fucaceae, including the genera Ascophyllum and Fucus, are the predominant intertidal macroalgae of the northern hemisphere. These algae are known to support abundant and diverse epifaunal assemblages, but seasonal changes in these assemblages have been poorly documented (e.g. Colman 1940, Dahl 1948, Ohm 1964, Hagerman 1966, Zavodnik 1967). Most studies have emphasized single taxa, or only the macrofauna, except for those of Colman (1940), Ohm (1964), and Hagerman (1966) which provided detailed taxonomic descriptions of all taxa in both the meiofaunal and macrofaunal size fractions.

This study investigates seasonal changes in the species composition and abundance of epifaunal assemblages (both meiofauna and macrofauna) on 2 common intertidal macroalgae, Ascophyllum nodosum and Fucus vesiculosus, on a rocky shore in Nova Scotia. Classification and ordination techniques are used to elucidate temporal patterns and to provide insight into the role of epiphytic algae as a determinant of assemblage structure and dynamics.

\section{MATERIALS AND METHODS}

Epifauna on Ascophyllum nodosum and Fucus vesiculosus were sampled monthly between May 1983 and June 1984 on the rocky shore of a moderately exposed bay at Lower Prospect, Nova Scotia (Fig. 1). The bay is shallow (mean depth $=3 \mathrm{~m}$ ) with a sand and cobble substratum. The shoreline consists of 


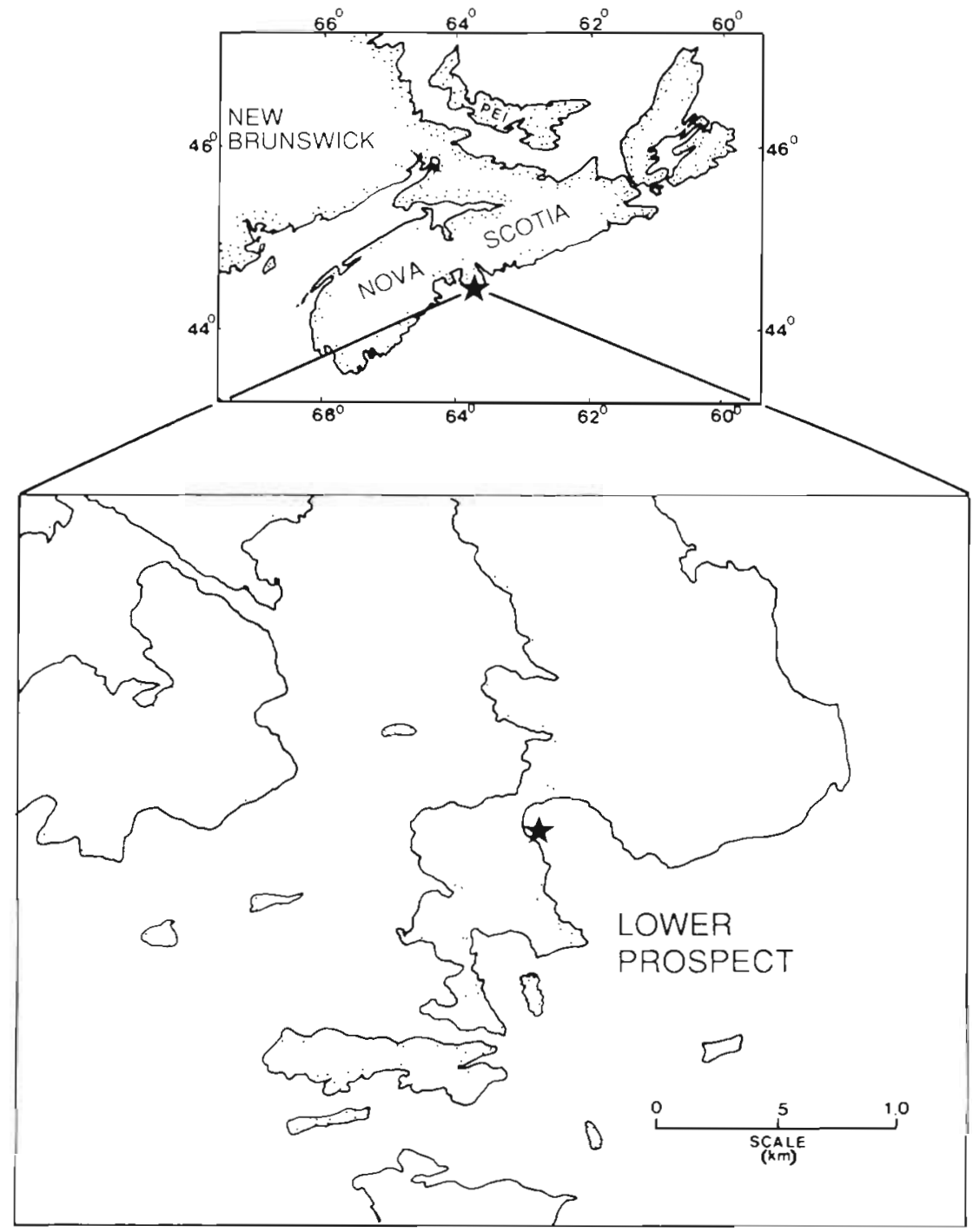

Fig. 1. Map of Nova Scotia, Canada, showing study site $(\star)$ at Lower Prospect gradually sloping bedrock extrusions separated by fine sand beaches. The intertidal macroalgal community is dominated by luxuriant beds of $A$. nodosum and $F$. vesiculosus.

Three specimens each of Ascophyllum nodosum and Fucus vesiculosus were collected from random locations along a $50 \mathrm{~m}$ transect approximately $0.1 \mathrm{~m}$ above mean low water shortly after exposure at low tide. Individual specimens were cut from their holdfasts and placed in plastic bags with $5 \%$ formaldehyde solution. Epifauna were washed from each specimen with filtered seawater through 0.50 and $0.063 \mathrm{~mm}$ sieves and hand-sorted under a dissecting microscope. The fraction retained on the $0.063 \mathrm{~mm}$ sieve was subsampled in May through September 1983, and May through June 1984; the entire fraction was sorted for all other months. Five replicate subsamples (1/20 volume) were taken using a large bore automatic pipette. (Counts were checked for agreement with a Poisson series indicating random sampling of all taxa.) Between 1 and 5 subsamples were sorted to include at least 200 specimens of the dominant taxa (excluding nematodes and crustacean nauplii which were extremely abundant). Epifauna were identified to species or to higher taxa for some groups (e.g. Foraminifera, Turbellaria, Nematoda, Ostracoda, Halacaridae, Chironomidae).

Filamentous epiphytic algae were scraped from Ascophyllum nodosum and Fucus vesiculosus with a scalpel and samples retained for identification. Macroalgal specimens were divided into distinct plant regions: blade, eroded blade, or stalk. Five pieces from each region were selected at random and photocopied. The surface area of these pieces was determined by computer-digitizing the photocopy images. Pieces from each region, the remaining portion of the macroalgal specimen, and the epiphytes were dried separately to a constant weight at $60.0^{\circ} \mathrm{C}$. For each region the ratio of surface area to dry weight was calculated as 
the average of the 5 pieces. The weight of a given region (weight of the pieces and remaining portion of that region) was then multiplied by the corresponding ratio to give the surface area for that region. Total plant surface area is the sum of the total surface area for each of the regions.

Density of epifauna is expressed as number of individuals $\mathrm{m}^{-2}$ of plant surface. The normality of the data was checked and the best transformation for each taxon was estimated using the procedure of Box et al. (1978). For all taxa, logarithmic transformation was indicated; $\log (x+1)$ was used to accommodate rare species. Differences among months and between macroalgal species were investigated by analysis of variance. Residual error terms were tested for normality, independence and noncorrelation using SAS procedures (Ray 1982). Transformation reduced departures from these assumptions, although ANOVA is a relatively robust test procedure especially when applied to balanced designs (Underwood 1981). Relations among samples were examined using the similarity matrix and classification program ORDANA (Bloom et al. 1977) and the non-metric multidimensional scaling program SCALO2 (Maquire 1969). Density data were double root transformed (Field et al. 1982) and a similarity matrix involving all taxa was constructed using the Bray Curtis Index (also known as Czekanowski's Quantitative Index) (Field et al. 1982). This matrix was used to construct classification diagrams of percent similarity using group average sorting (Field et al. 1982). It was also used in non-metric multidimensional scaling analysis (Kruskal 1964a, b, Field et al. 1982).

\section{RESULTS}

\section{Habitat description}

Surface water temperatures (recorded monthly) ranged from $-1.0^{\circ} \mathrm{C}$ (Jan 1984) to $18.7^{\circ} \mathrm{C}$ (Jul 1983) and air temperatures ranged from $-4.5^{\circ} \mathrm{C}$ (Jan 1984) to $25.0^{\circ} \mathrm{C}$ (Jun 1984) (Fig. 2). Temperatures within the macroalgal bed are lower in the summer and higher in the winter than the air temperatures, demonstrating a thermal buffering capacity of the mat. An ice sheet, several centimetres thick, frequently formed during low tide on the surface of the algal mat in January and February. Sea surface salinity ranged from 29.0 to $31.1 \%$.

The abundance of macroalgae did not vary noticeably throughout the year. In September 1983, mean biomass ( $\pm \mathrm{SE}$ ) was $2.7 \pm 1.2 \mathrm{~kg}$ dry weight $\mathrm{m}^{-2}$ rock surface for Ascophyllum nodosum, and $0.6 \pm 0.2 \mathrm{~kg}$ dry weight $\mathrm{m}^{-2}$ rock surface for Fucus vesiculosus.

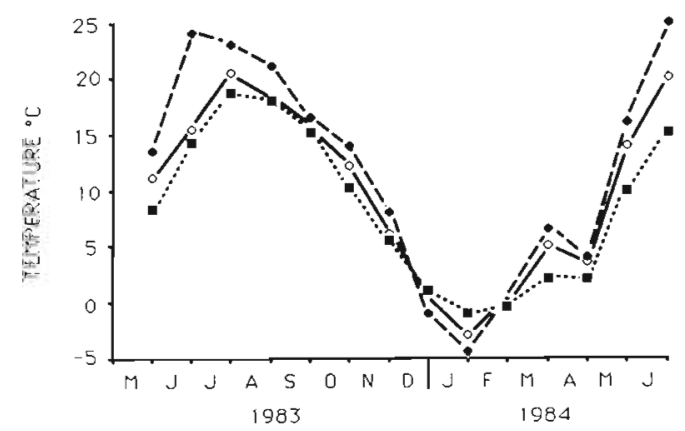

Fig. 2. Water (๑), air $(\bullet)$, and algal mat $(\diamond)$ temperatures (measured with a mercury thermometer) at sampling times between May 1983 and Jun 1984 at Lower Prospect, Nova Scotia

Two-way ANOVA indicates that the biomass of epiphytic algae on $A$. nodosum and $F$. vesiculosus (Fig. 3) varied significantly among months $(p<0.001)$ and between the 2 macroalgal species $(p<0.001)$ with a significant interaction between month and macroalgal species $(p<0.01$ ). (A significant interaction indicates that the direction of difference between macroalgal species varied among months.) Epiphytes were abundant in the spring and summer and rare to absent through the late fall and winter. Elachistea fucicola (Vell.) Aresch. and Pilaiella littoralis (L.) Kjellm were the dominant epiphytic species; other species included Ptilota serrata Kutz., Bonnemaisonia hamifera Hariot., and Leptonematella fasciculata (Reinke) Silvia.

\section{Seasonal patterns in density}

Fifty-three species or multispecies groupings (Appendices 1 \& 2) were identified from Ascophyllum nodosum and Fucus vesiculosus. The density of the total epifauna shows pronounced seasonal variation (Fig. 4; Appendices 1 \& 2). Density on both macroaigal

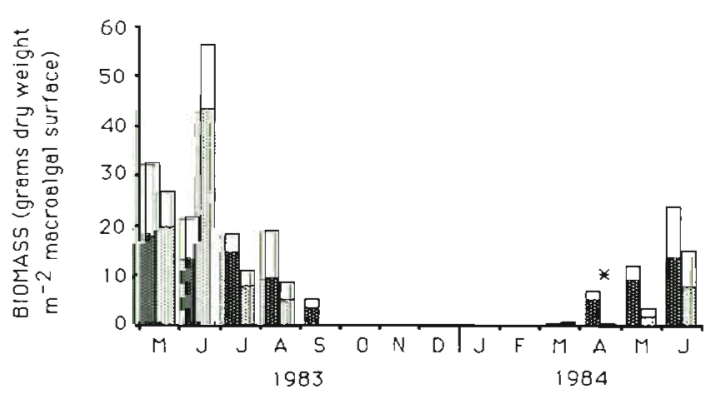

Fig. 3. Biomass of filamentous epiphytic algae on Ascophyllum nodosum and Fucus vesiculosus at Lower Prospect, Nova Scotia. Dark shading: mean density on $A$. nodosum; light shading: mean density on $F$. vesiculosus; open: 1 standard error of the mean. Sample size is 3 for each macroalgal species. (*) Months with statistically significant differences between macroalgal species (t-test, $p<0.05$ ) 


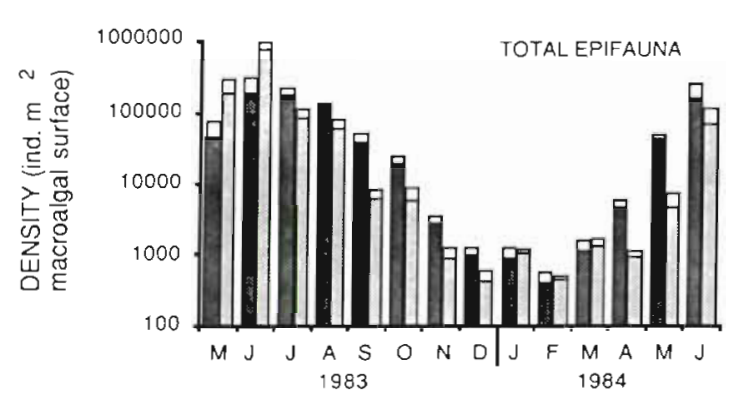

Fig. 4. Density of total epifauna on Ascophyllum nodosum and Fucus vesiculosus collected at Lower Prospect. Nova Scotia. See Fig. 3 for explanation of shading. Sample size is 3 for each macroalgal species

species was maximal in June 1983 and declined by 2 orders of magnitude to a minimum in mid winter.

Eighteen species or multispecies groupings of harpacticoid copepods from 9 families are identified from both Ascophyllum nodosum and Fucus vesiculosus (Appendices 1 \& 2). Harpacticoids (including nauplii) were the most abundant component of the epifaunal assemblages of both macroalgal species, representing
31 to $82 \%$ of the epifauna of $A$. nodosum and 32 to $70 \%$ of the epifauna of $F$. vesiculosus (Fig. 5). Density of copepod nauplii was comparable to that of adults and copepodites in most months (Fig. 6). Maximum density of harpacticoid copepods and nauplii occurred around June on both macroalgal species although the period of peak abundance was more protracted on $A$. nodosum than on $F$. vesiculosus (Fig. 6).

The density of each of the major harpacticoid species (or multispecies groupings) varied significantiy among months and between macroalgal species (with the exception of Harpacticus sp. 2, Parastenhelia spinosa, and Heterolaophonte discophora) (Tables 1 \& 2). Except for Harpacticus sp. 2, Tisbe spp., Mesochra sp. 1 , and $H$. discophora the interactions between month and macroalgal species were significant. Density of most species was highest between June and August and declined throughout the fall and winter. During the period of maximum abundance, the genus Heterolaophonte was dominant (Fig. 7). Other numerically important species at this time include Harpacticus sp. 2, P. spinosa, Amphiascopsis sp., Mesochra sp. 2, and Nitocra typica (on Fucus vesiculosus only).
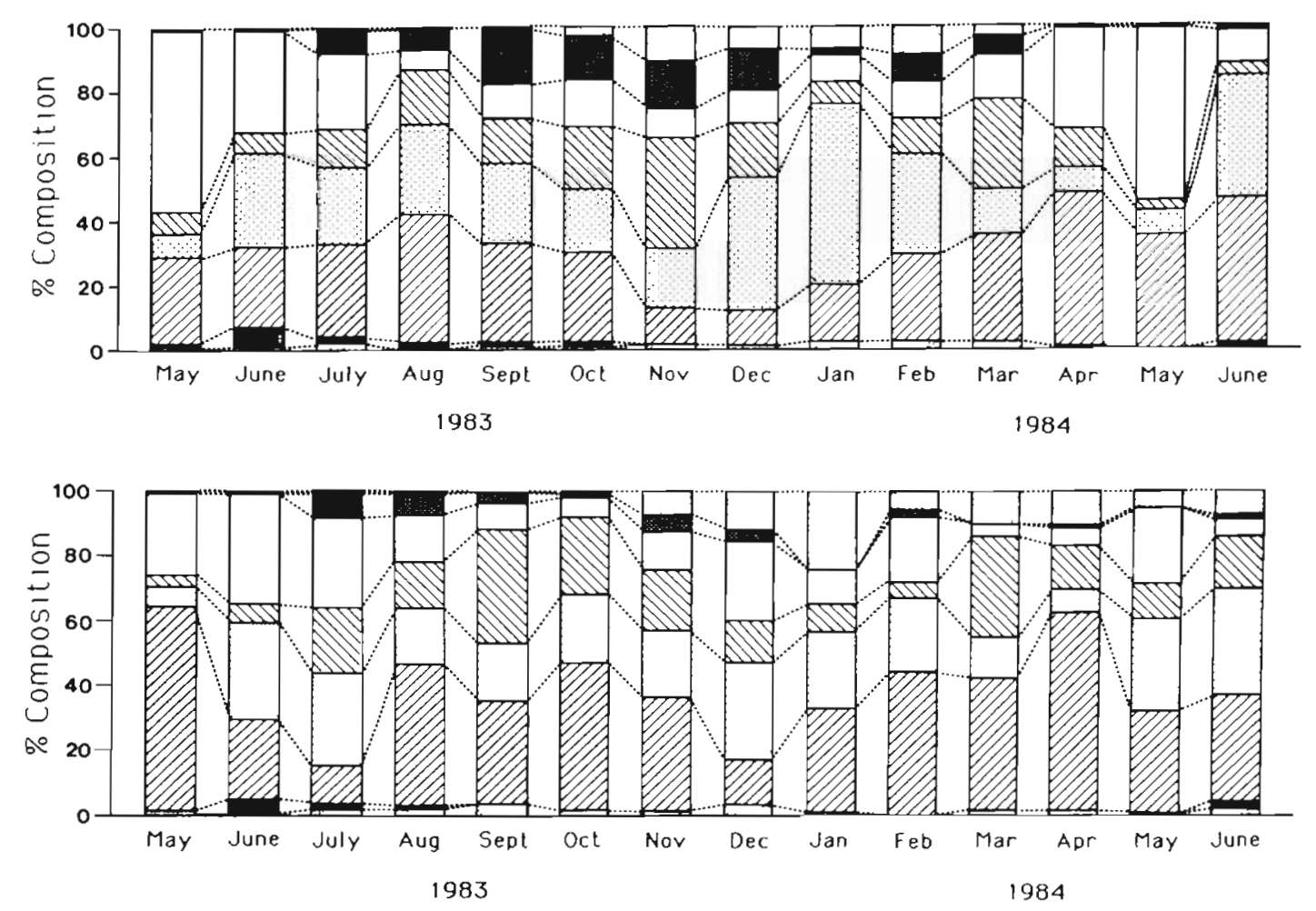

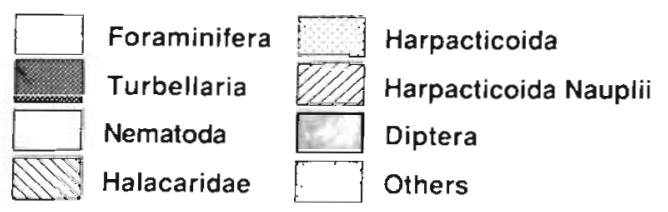

Fig. 5. Percentage composition of major epifaunal taxa on Ascophyllum nodosum (top) and Fucus vesiculosus (bottom) collected at Lower Prospect. Nova Scotia 

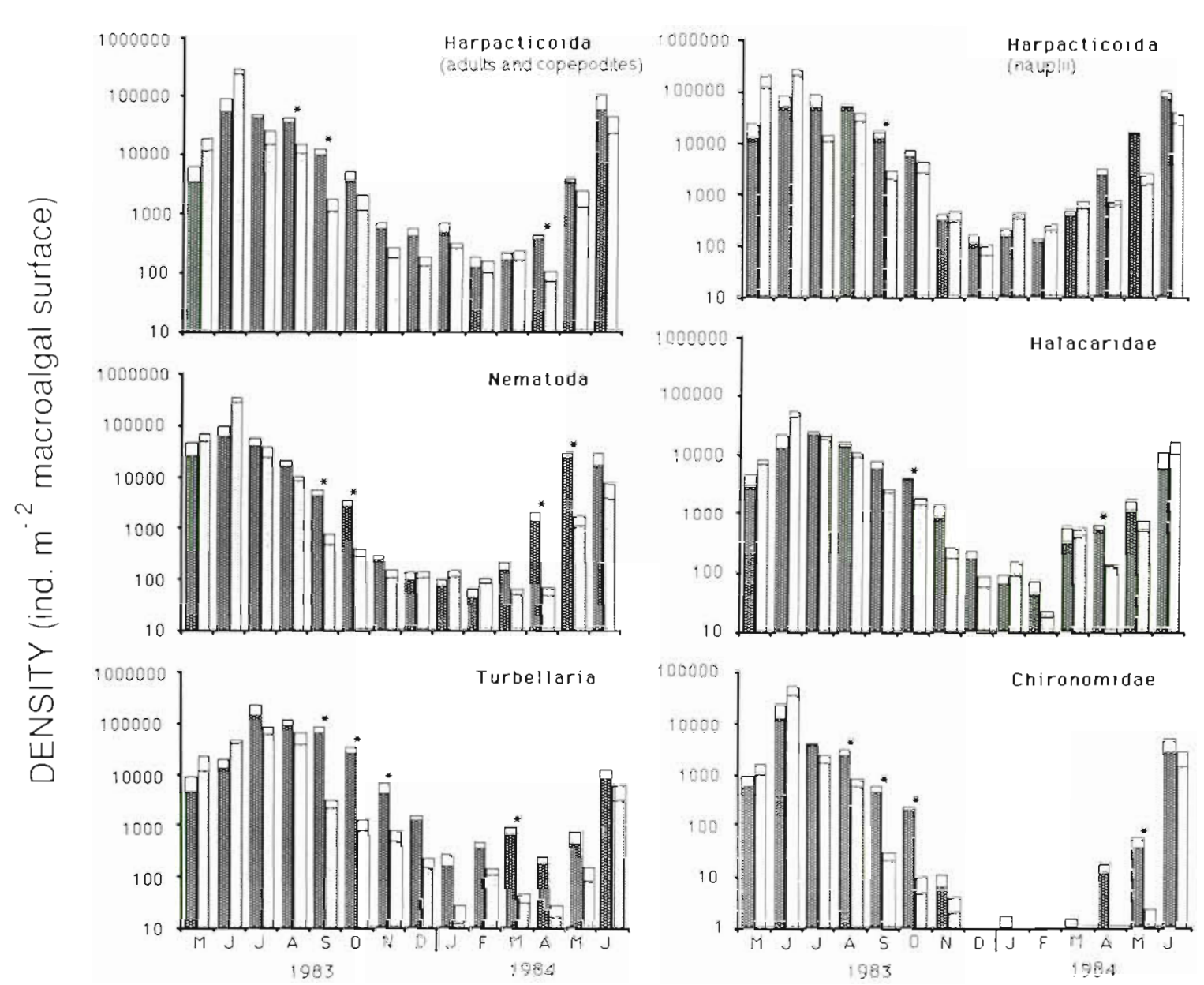

Fig. E. Density of major taxa on Ascophyllum nodosum and Fucus vosiculosus collected at Lower Prospect, Nova Scotia See Fig. 3 for explanation of shading. Sample size is 3 for each macroalgal species. ( $\star$ ) Months with statistically significant differences between macroalgal species (t-test, $\mathrm{p}<0.05$ )

Mesochra sp. 1 and $N$. typica (on Ascophyllum nodosum) were most abundant in the fall and early winter (Fig. 7). Tisbe spp. showed little seasonal fluctuation in density (Fig. 7).

Nematodes were the second most abundant taxon, representing 8 to $56 \%$ of the epifauna on Ascophyllum nodosum and 5 to $34 \%$ of the epifauna on Fucus vesiculosus (Fig. 5). Nematode density varied significantly between macroalgal species and among months with a significant interaction between month and macroalgal species (Table 1). Maximum density on both macroalgal species occurred in June 1983; density declined by 3 orders of magnitude during the fall and remained low throughout the winter (Fig. 6).

Halacarid mites represented about 3 to $35 \%$ of the epifauna on both macroalgal species (Fig. 5). Density of halacaridae varied significantly among months but not between macroalgal species with a significant interaction between month and macroalgal species (Table 1). Density was maximum around June and July 1983 on both macroalgal species respectively, and declined by 2 to 3 orders of magnitude by February 1984 (Fig. 6). Members of the genus Rhombognathides accounted for $>90 \%$ of the total mite density on both macroalgal species throughout the year.

Turbellarians represented $<1$ to $16 \%$ of the epifauna on Ascophyllum nodosum and $<1$ to $8 \%$ of the epifauna on Fucus vesiculosus (Fig. 5). Pronounced seasonal changes in density of turbellaria occurred on both macroalgal species (Fig. 6). Turbellarian density varied significantly between macroalgal species and among months (Table 1). Maximum density on both macroalgal species occurred in July 1983; density declined during the fall and remained low throughout the winter. One species, Notoplana atomata, and a multispecies grouping were identified. Density of $N$. atomata reached a maximum in September 1983 on both macroalgal species $(N$. atomata accounted $<18$ and $<9 \%$ of all turbellarians present on $A$. nodosum and $F$. vesiculosus respectively in any month).

Chironomid larvae and pupae represented from 0 to $7 \%$ of the epifauna on Ascophyllum nodosum and 0 to 
Table 1. Ascophyllum nodosum and Fucus vesiculosus. Two way ANOVA of the density of major epifaunal taxa between 2 macroalgal species and among 14 mo. Data are F-values with corresponding probability levels: $p<0.05, \quad \cdots p<0.01$, $\cdots p<0.001$, ns, not significant

\begin{tabular}{|c|c|c|c|}
\hline Taxon & Month & $\begin{array}{l}\text { Algal } \\
\text { species }\end{array}$ & Interaction \\
\hline Foraminifera & $7.17^{\cdots}$ & $0.01 \mathrm{~ns}$ & $2.91^{\cdots}$ \\
\hline Turbellaria & $25.33^{\cdots} \cdots$ & $36.80^{\cdots} \cdots$ & $1.82 \mathrm{~ns}$ \\
\hline Nemertinea & $18.06^{\cdots} \cdots$ & $4.00^{\circ}$ & $1.58 \mathrm{~ns}$ \\
\hline Nematoda & $39.72 \cdots$ & $16.92 \cdots$ & $4.36^{\cdots} \cdots$ \\
\hline Annelida & $31.38^{\cdots} \cdots$ & $12.52 \cdots$ & $3.27^{\cdots}$ \\
\hline Gastropoda & $19.47^{\cdots} \cdots$ & $1.05 \mathrm{~ns}$ & $0.47 \mathrm{~ns}$ \\
\hline Bivalvia & $15.65^{\cdots} \cdots$ & $5.74^{\circ}$ & $2.04^{\circ}$ \\
\hline Halacaridae & $37.61 \cdots$ & $0.88 \mathrm{~ns}$ & $2.38^{\circ}$ \\
\hline Ostracoda & $0.89 \mathrm{~ns}$ & $1.56 \mathrm{~ns}$ & $0.83 \mathrm{~ns}$ \\
\hline $\begin{array}{l}\text { Harpacticoida } \\
\text { (adults and } \\
\text { copepodites) }\end{array}$ & $27.93^{\cdots} \cdots$ & $15.09 \cdots$ & $2.15^{\circ}$ \\
\hline $\begin{array}{l}\text { Harpacticoida } \\
\text { (nauplii) }\end{array}$ & $33.28 \cdots$ & $3.84 \mathrm{~ns}$ & $3.18^{\circ}$ \\
\hline Calanoida & $37.34^{\cdots}$ & $1.78 \mathrm{~ns}$ & $1.07 \mathrm{~ns}$ \\
\hline Isopoda & $11.60^{\cdots} \cdots$ & $1.17 \mathrm{~ns}$ & $0.71 \mathrm{~ns}$ \\
\hline Amphipoda & $29.19 \cdots$ & $0.09 \mathrm{~ns}$ & $1.39 \mathrm{~ns}$ \\
\hline Diptera & $48.86^{\cdots}$ & $20.42 \cdots$ & $2.80^{\circ}$ \\
\hline
\end{tabular}

Table 2. Ascophyllum nodosum and Fucus vesiculosus. Twoway ANOVA of the density of major harpacticoid species between 2 macroalgal species and among 14 mo. Data are Fvalues with corresponding probability levels: " $p<0.05$, $\cdots p<0.01, \cdots p<0.001, n s$, not significant

\begin{tabular}{|c|c|c|c|}
\hline Species & Month & $\begin{array}{l}\text { Algal } \\
\text { species }\end{array}$ & Interaction \\
\hline Harpacticus sp. 2 & $8.80^{\cdots}$ & $3.58 \mathrm{~ns}$ & $0.60 \mathrm{~ns}$ \\
\hline Tisbe spp. & $4.82^{\cdots}$ & $4.44^{\circ}$ & $0.63 \mathrm{~ns}$ \\
\hline Thalestris purpurea & $5.36^{\cdots} \cdots$ & $10.14^{\cdots}$ & $2.44^{\circ}$ \\
\hline Parastenhelia spinosa & $5.54^{\cdots} \cdots$ & $1.55 \mathrm{~ns}$ & $3.12^{\circ}$ \\
\hline Amphiascopsis sp. & $10.09^{\cdots} \cdot$ & $9.53 \cdots$ & $3.14^{\cdots}$ \\
\hline Nitocra typica & $10.40^{\cdots} \cdot$ & $18.21 \cdots$ & $2.27^{*}$ \\
\hline Mesochra sp. 1 & $4.82^{\cdots} \cdots$ & $44.62 \cdots$ & $1.29 \mathrm{~ns}$ \\
\hline Mesochra sp. 2 & $28.49^{\cdots} \cdot$ & $41.81 \cdots$ & $2.94^{*}$ \\
\hline $\begin{array}{l}\text { Heterolaphonte } \\
\text { discophora (adults) }\end{array}$ & $16.65^{\cdots} \cdot$ & $3.98 \mathrm{~ns}$ & $1.53 \mathrm{~ns}$ \\
\hline $\begin{array}{l}\text { Heterolaophonte spp. } \\
\text { (adults) }\end{array}$ & $50.85^{\cdots}$ & $16.46^{\cdots} \cdots$ & $2.69^{*}$ \\
\hline $\begin{array}{l}\text { Heterolaophonte spp. } \\
\text { (juveniles) }\end{array}$ & $52.27 \cdots$ & $8.84^{\cdots}$ & $3.86^{\cdots}$ \\
\hline
\end{tabular}

$4 \%$ of the epifauna on Fucus vesiculosus (Fig. 5). Chironomid density varied significantly among months and between macroalgal species with a significant interaction between month and macroalgal species (Table 1). Densities increased markedly from May 1983 to a maximum in June 1983 on both macroalgal species (Fig. 6), then declined rapidly during the summer and fall. The marked decline in density is in part due to the emergence of adults from pupae over this time. Chironomids were rare or absent throughout the winter and spring.

Other less abundant taxa included Foraminifera, Nemertinea, Annelida, Gastropoda, Bivalvia, Ostracoda, Calanoida, Isopoda, and Amphipoda (Fig. 8 ; Appendices $1 \& 2$ ). With the exception of Ostracoda, the density of these minor taxa varied significantly among months (Table 1). Seasonal fluctuations in density were similar among all these taxa with the exception of Foraminifera on Ascophyllum nodosum, and Ostracoda and Calanoida on both macroalgal species. Densities generally increased during the spring reaching maxima between June and August 1983. Densities generally declined rapidly throughout the summer and early fall, although some taxa (e.g. Isopoda) had a more protracted period of maximal density. Nemertinea, Gastropoda, Isopoda and Amphipoda were rare or absent throughout the winter, while other minor taxa occurred at low densities. The densities of Nemertinea, Annelida, and Bivalvia varied significantly between macroalgal species (Table 1). The interaction between month and macroalgal species was significant for Annelida and Bivalvia.

The density of most major harpacticoid species, total harpacticoid density (including nauplii) and the total density of most other major (nematodes, halacarid mites, tubellarians and chironomids) and minor taxa were positively correlated with epiphyte biomass on both macroalgal species (Tables 3 \& 4).

\section{Classification and ordination}

Bray-Curtis similarity coefficients were calculated between macroalgal samples for both Ascophyllum nodosum and Fucus vesiculosus. Dendrograms produced by group average clustering of these values show 2 distinct clusters separating at approximately 42 and $35 \%$ similarity for $A$. nodosum (Fig. 9) and $F$. vesiculosus (Fig. 10) respectively. These clusters correspond closely to the periods May through October, and November through April. For A. nodosum, these clusters subdivide into 4 clusters at approximately $60 \%$ similarity, generally corresponding to the periods: (A) June through October; (B) May; (C) November, March, April; (D) December through February. For $F$. vesiculosus 4 clusters at approximately $52 \%$ similarity corresponded closely to the periods: (A) September, May, June, October; (B) June through August; (C) October, November, March, April; (D) December through February. Samples collected within months were generally most similar to each other.

Ordination by multidimensional scaling (MDS) of macroalgal samples yielded results similar to those of 

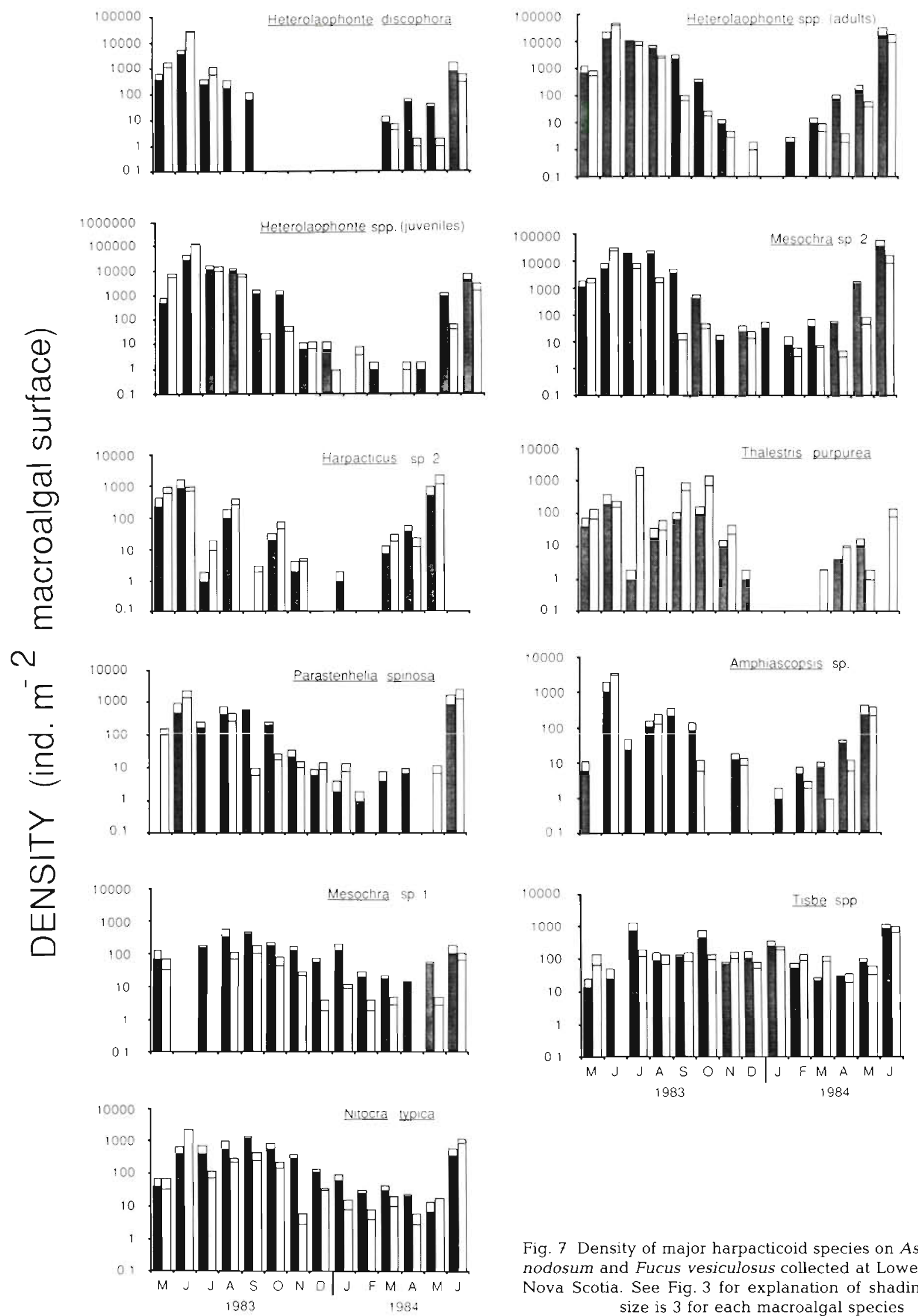

Fig. 7 Density of major harpacticoid species on Ascophyllum nodosum and Fucus vesiculosus collected at Lower Prospect, Nova Scotia. See Fig. 3 for explanation of shading. Sample size is 3 for each macroalgal species 


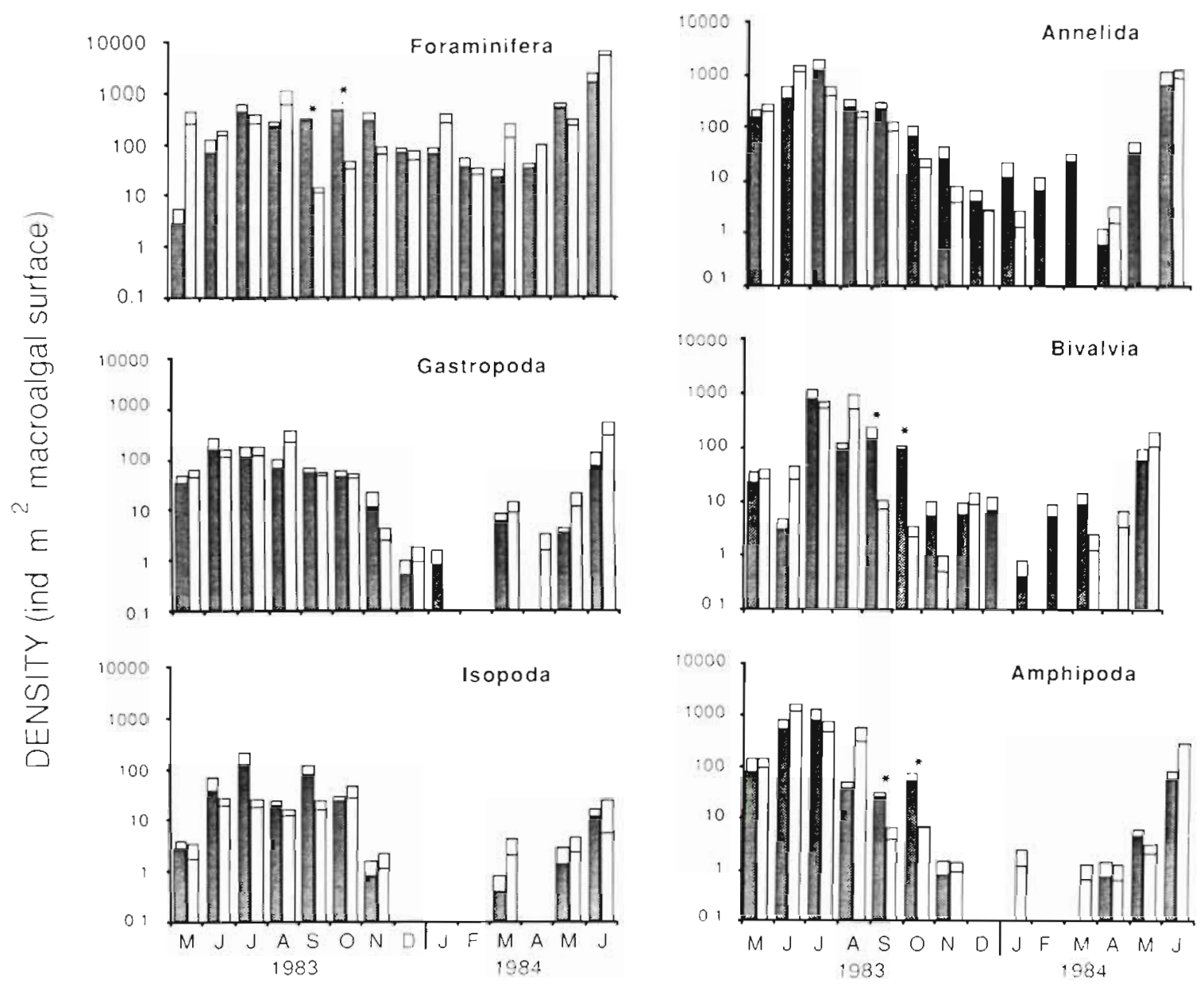

Fig. 8. Density of minor taxa on Ascophyllum nodosum and Fucus vesiculosus collected at Lower Prospect, Nova Scotia. See Fig. 3 for explanation of shading. Sample size is 3 for each macroalgal species. (*) Months with statistically significant differences between macroalgal species (t-test, $p<0.05$ )

Table 3. Ascophyllum nodosum and Fucus vesiculosus. Relationship of density of major epifaunal taxa and epiphyte biomass for months where macroscopic epiphytic algae were present. Data are Spearman rank correlation coefficients and corresponding probability levels: $p<0.05, \quad \cdots p<0.01$, $\cdots p<0.001$, ns, not significant. Sample size is 36 for $A$. nodosum and 30 for $F$. vesiculosus.

\begin{tabular}{|lll|}
\hline Taxon & A. nodosum & F. vesiculosus \\
\hline Turbellaria & $0.308 \mathrm{~ns}$ & $0.561 \cdots$ \\
Nematoda & $0.842 \cdots$ & $0.853 \cdots$ \\
Annelida & $0.541 \cdots$ & $0.538 \cdots$ \\
Gastropoda & $0.409 \cdot$ & $0.491 \cdots$ \\
Bivalvia & $0.177 \mathrm{~ns}$ & $0.449 \cdots$ \\
Halacaridae & $0.630 \cdots$ & $0.824 \cdots$ \\
Harpacticoida & $0.723 \cdots$ & $0.774 \cdots$ \\
$\quad$ (adult and & & \\
$\quad$ copepodites) & & \\
Harpacticoida & $0.767 \cdots$ & $0.756 \cdots$ \\
$\quad$ (nauplii) & & \\
Isopoda & $0.276 \mathrm{~ns}$ & $0.171 \mathrm{~ns}$ \\
Amphipoda & $0.576 \cdots$ & $0.769 \cdots$ \\
Diptera & $0.688 \cdots$ & $0.799 \cdots$ \\
Total fauna & $0.809 \cdots$ & $0.789 \cdots$ \\
\hline
\end{tabular}

Table 4. Ascophyllum nodosum and Fucus vesiculosus. Relationship of density of harpacticoid copepods and epiphyte biomass for months where macroscopic epiphytic algae were present. Data are Spearman rank correlation coefficients and corresponding probability levels: " $p<0.05, \quad \cdots p<0.01$, $\cdots p<0.001$, ns, not significant. Sample size is 36 for $A$. nodosum and 30 for $F$. vesiculosus

\begin{tabular}{|c|c|c|}
\hline Species & A. nodosum & F. vesiculosus \\
\hline Harpacticus sp. 2 & $0.357^{\circ}$ & $0.471 \cdots$ \\
\hline Tisbe spp. & $0.125 \mathrm{~ns}$ & $0.413^{\circ}$ \\
\hline Thalestris purpurea & $0.062 \mathrm{~ns}$ & $0.113 \mathrm{~ns}$ \\
\hline Parastenhelia spinosa & $0.128 \mathrm{~ns}$ & $0.507^{\cdots}$ \\
\hline Amphiascopsis sp. & $0.290 \mathrm{~ns}$ & $0.281 \mathrm{~ns}$ \\
\hline Nitocra typica & $0.042 \mathrm{~ns}$ & $0.302 \mathrm{~ns}$ \\
\hline Mesochra sp. 1 & $0.193 \mathrm{~ns}$ & $0.284 \mathrm{~ns}$ \\
\hline Mesochra sp. 2 & $0.760^{\cdots}$ & $0.826^{\cdots} \cdot$ \\
\hline $\begin{array}{l}\text { Heterolaophonte } \\
\text { discophora }\end{array}$ & $0.757^{\cdots} \cdots$ & $0.711^{\cdots}$ \\
\hline $\begin{array}{l}\text { Heterolaophonte spp. } \\
\text { (adult) }\end{array}$ & $0.734^{\cdots} \cdots$ & $0.775^{\cdots} \cdots$ \\
\hline $\begin{array}{l}\text { Heterolaophonte spp. } \\
\text { (juvenile) }\end{array}$ & $0.654 \cdots$ & $0.813 \cdots$ \\
\hline
\end{tabular}




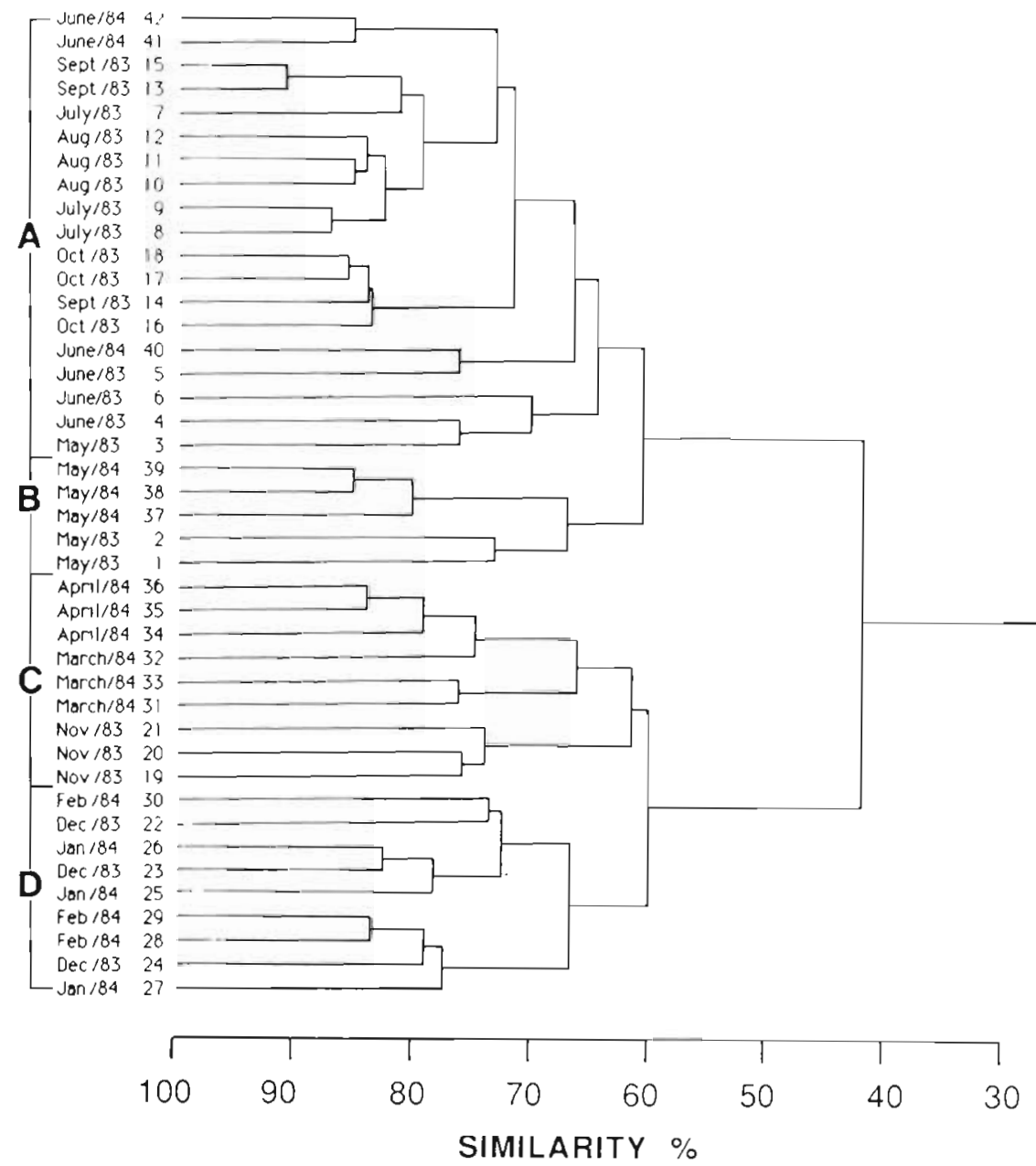

Fig. 9. Ascophyllum nodosum. Dendrogram of percentage similarity (Bray-Curtis measure) of faunal composition among 42 samples collected over 14 mo at Lower Prospect, Nova Scotia. Four main clusters (A, B, C, D) are delineated at approxiinatcly the $60 \%$ similarity !evel

cluster analysis for both Ascophyllum nodosum (Fig. 11) and Fucus vesiculosus (Fig. 12). Clusters of samples from the corresponding classification dendrograms have been delineated on these plots. Samples within months generally show the closest proximity (similarity). The distribution of samples shows a clear relation with epiphytic algal biomass. For both $A$. nodosum and $F$. vesiculosus, epiphyte density generally decreases from the lower left to the upper right of these figures. In general, where samples within months did not group well, between-sample variability in epiphytic algal biomass is high. Stress values (relating to the effectiveness of MDS in representing actual similarities between samples) for the 2-dimensional solutions are 0.102 and 0.087 for $A$. nodosum and $F$, vesiculosus respectively, indicating a satisfactory representation of similarities between samples (Kruskal 1964a).

The program ORDANA is limited to $<51$ samples. To enable comparisons of faunal similarity between macroalgal species, the samples were split into 2 groups: May through October, and November through April based on the above clustering and ordination results (Fig. 9 \& 10). Samples from May through October separate at $56 \%$ similarity into 2 major clusters (Fig. 13). These clusters show no clear trends with respect to month or macroalgal species. Both macroalgal species and all months except July, August, and October are common to both clusters (Fig. 13). (Samples from October occur only in Cluster $A_{\text {; }}$ samples from July and August occur only in Cluster B.) Ordination by multidimensional scaling of these samples for both macroalgal species supports these results (Fig. 14). Clusters of samples from the corresponding dendrogram are delineated on this plot. Epiphyte biomass decreases from the lower left to upper right of this plot. Samples in Cluster A have lowest epiphyte biomass (Fig. 14). The stress of this 2-dimensional solution is 0.132 , indicating a satisfactory representation of similarities between samples (Kruskal 1964a).

Samples from November through April separate at $57 \%$ similarity into 2 clusters closely corresponding to the periods: (A) November, March, April; (B) December through February (Fig. 15). The 2 macroalgal species tend to cluster separately at approximately 


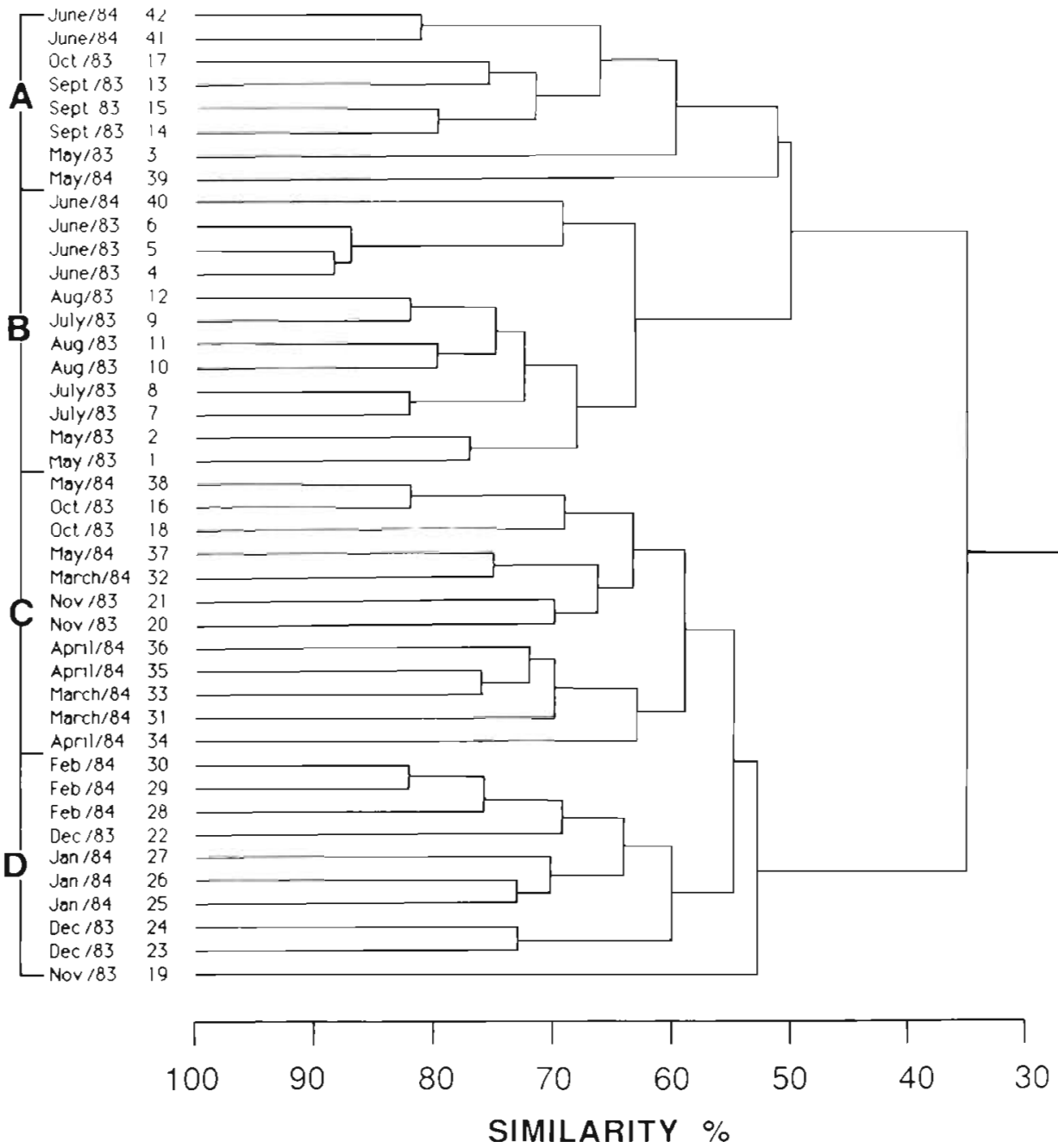

Fig. 10. Fucus vesiculosus. Dendrogram of percentage similarity (Bray-Curtis measure) of faunal composition among 42 samples collected over 14 mo at Lower Prospect, Nova Scotia. Four main clusters (A, B, C, D) are delineated at approximately the $52 \%$ similarity level
58 and $62 \%$ similarity within Clusters A and B respectively. Separation of samples by macroalgal species is particularly apparent in samples from December through February (Cluster B). Ordination by multidimensional scaling supports these results (Fig. 16). The stress of this representation is 0.200 indicating a poor representation of actual similarities between samples (Kruskal 1964a).

\section{DISCUSSION}

The composition of the epifaunal assemblages of Ascophyllum nodosum and Fucus vesiculosus in this study is similar to that reported for intertidal $A$. nodosum and $F$. vesiculosus in England (Colman 1940), subtidal $F$. vesiculosus and $F$. serratus in Germany (Ohm 1964), and subtidal F. serratus in Denmark (Hagerman 1966). These assemblages are dominated by harpacticod copepods and their nauplii, and contain many of the meiofaunal families and genera which constitute the 'typical' phytal fauna (see reviews by Coull et al. 1983, Hicks 1985). The composition of the harpacticoid epifauna corresponds closely to that previously reported for macroalgae (Colman 1940, Ohm 1964, Hagerman 1966, Hicks 1980, 1985) or macroalgal debris (Marcotte 1977). The harpacticoid families Harpacticidae, Tisbidae, and Diosaccidae are typically phytal dwelling (Hicks 1977b). The families Laophontidae and Canthocamptidae are more characteristic of sediment biotopes (Hicks 1977b), although several species of these families are also abundant on $A$ nodosum, F. vesiculosus, and $F$. serratus (Colman 1940 , Ohm 1964, Hagerman 1966, Hicks 1980).

Pronounced seasonal changes in density and species composition are evident for most components of the epifaunal assemblage of both Ascophyllum nodosum and Fucus vesiculosus in this study. Seasonal variation in epifauna has been documented previously for intertidal macroalgae (Gunnill 1983) and subtidal macroalgae (Ohm 1964, Hagerman 1966, Mukai 1971, Haage 1975, Edgar 1983). Variations in density reflect popula- 


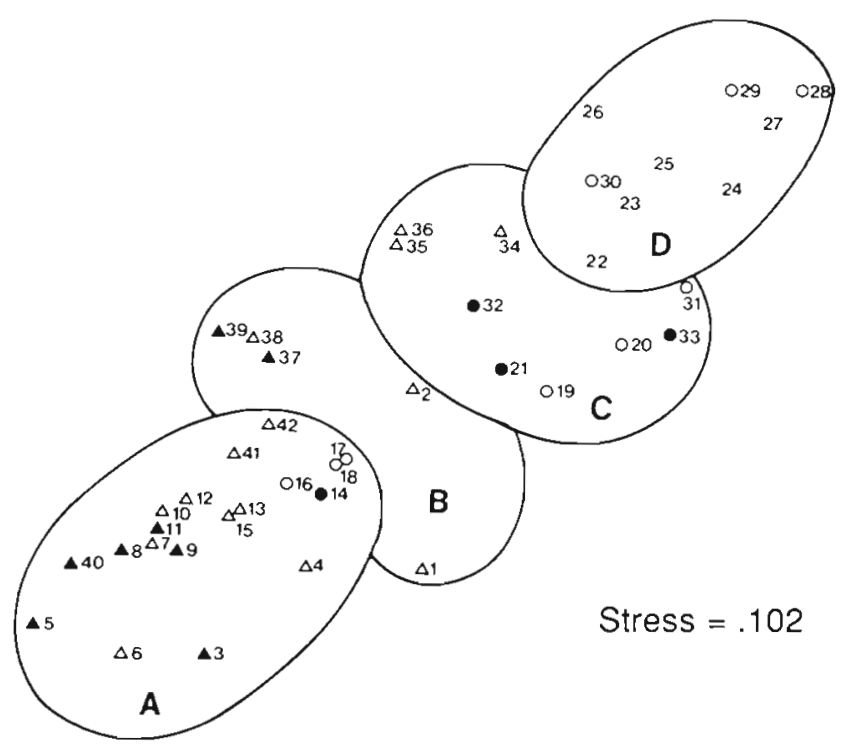

Fig. 11. Ascophyllum nodosum. Ordination by multidimensional scaling of 42 samples collected over 14 mo at Lower Prospect, Nova Scotia. Four clusters (A, B, C, D) of samples are delineated visually based on the dendrogram in Fig. 9 Symbols indicate different levels of epiphytic algal biomass ( $\mathrm{g}$ dry weight $\mathrm{m}^{-2}$ macroalgal surface) in samples: no symbol, $0 \mathrm{~g} \mathrm{~m}^{-2} ;(O)<0.1 \mathrm{~g} \mathrm{~m}^{-2} ;(\bullet) \geq 0.1,<1.0 \mathrm{~g} \mathrm{~m}^{-2} ;(\Delta) \geq 1.0$ $<10.0 \mathrm{~g} \mathrm{~m}^{-2} ;(\Delta) \geq 10.0,<100.0 \mathrm{~g} \mathrm{~m}^{-2}$

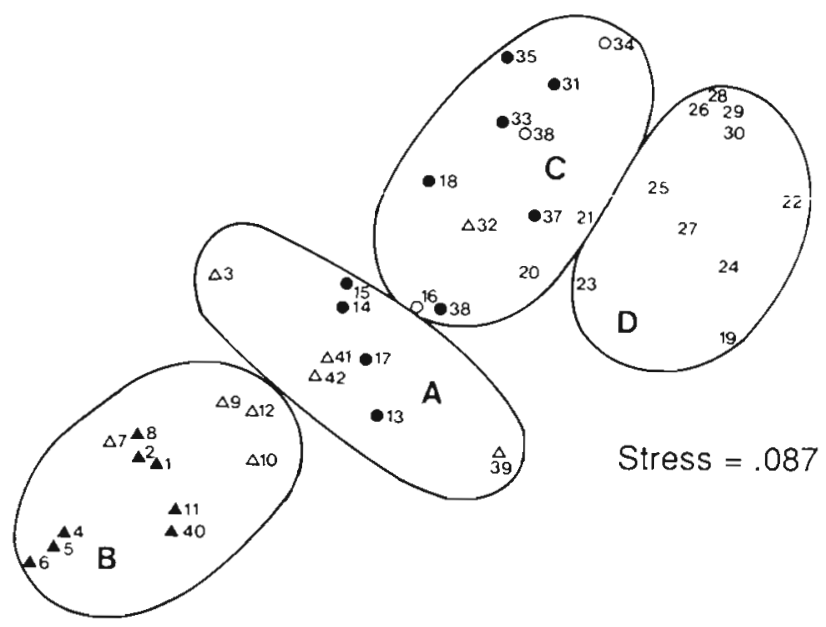

Fig. 12. Fucus vesiculosus. Ordination by multidimensional scaling of 42 samples collected over 14 mo at Lower Prospect, Nova Scotia. Four clusters (A, B, C, D) of samples are delineated visually based on the dendrogram in Fig. 10. Symbols indicate different levels of epiphytic algal biomass ( $g$ dry weight $\mathrm{m}^{-2}$ macroalgal surface) in samples: no symbol, $0 \mathrm{~g}$ $\mathrm{m}^{-2} ;(0)<0.1 \mathrm{~g} \mathrm{~m}^{-2} ;(\bullet) \geq 0.1,<1.0 \mathrm{~g} \mathrm{~m}^{-2} ;(\Delta) \geq 1.0,<10.0$ $\mathrm{g} \mathrm{m}^{-2} ;(\Delta) \geq 10.0,<100.0 \mathrm{~g} \mathrm{~m}^{-2}$

tion dynamics, which are controlled by a complex interplay of physical and biological factors. Fluctuations in the density of epifaunal taxa in this study generally exceed those previously reported. This may be due in part to the relatively harsh physical environment at Lower Prospect. Low epifaunal densities on subtidal $F$. serratus in the Oresund have been related to low water temperatures (Hagerman 1966). However, most seasonal studies of macroalgal epifauna have been limited to more temperate regions where water temperatures do not fall below $7.0^{\circ} \mathrm{C}$.

Epiphytic algae appear to have a pronounced effect on the abundance and species composition of the epifauna of Ascophyllum nodosum and Fucus vesiculosus. The density of most major taxa was positively correlated with epiphyte biomass, and cluster analysis and multidimensional scaling indicated that sample groupings were strongly related to epiphytic algal biomass. A similar relation has been reported previously for various macroalgal species (Colman 1940, Hagerman 1966, Zavodnick 1967, Nagel 1968, Kangas 1978, Gunnill 1982, 1983, Edgar 1983). Epiphytic algae and associated microflora (bacteria, diatoms, fungi) represent abundant and diverse food resources. Amphipods (Hagerman 1966, McBane \& Croker 1983, Pederson \& Capuzzo 1984, D'Antonio 1985), gastropods (Hagerman 1966, D'Antonio 1985) and chironomid larvae (Hagerman 1966, Morley \& Ring 1972) are known to graze epiphytic algae. Harpacticoid copepods and nematodes consume microbial films and may exhibit very specific food preferences (Lee et al. 1976, Hicks

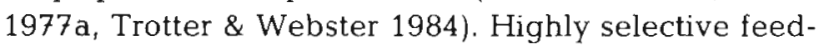
ing by members of the epifaunal community may allow for the coexistence of a wide variety of morphologically similar species.

The presence of epiphytic algae increases microhabitat complexity providing spatial refuges which may reduce predation on the epifauna (Coull \& Wells 1983). Conversely, the presence of epiphytic algae may enhance predation rates on some species by attracting predators. Pederson \& Capuzzo (1984) showed that the amphipod Calliopius laeviusculus is attracted to the epiphytes of Fucus which it consumes along with associated harpacticoid copepods. Increased structural complexity afforded by epiphytic algae also increases opportunities for attachment, enabling species to become established or to maintain their position on macroalgae when subjected to wave action or currents. Microhabitat structure is especially important for those species or life history stages which are poor swimmers. Populations may spread from refuge areas (e.g. the subtidal or areas of low wave exposure) to take advantage of seasonal increases in epiphyte abundance (Edgar 1983).

Dessication is another important factor controlling the distribution and abundance of epifaunal species on intertidal macroalgae (Gunnill 1983). Due to the thickness of the macroalgal mat at Lower Prospect, only the surface layer dried at low tide while the inner fronds remained wet. The algal mat also provides some thermal buffering: temperatures within the mat were up to 


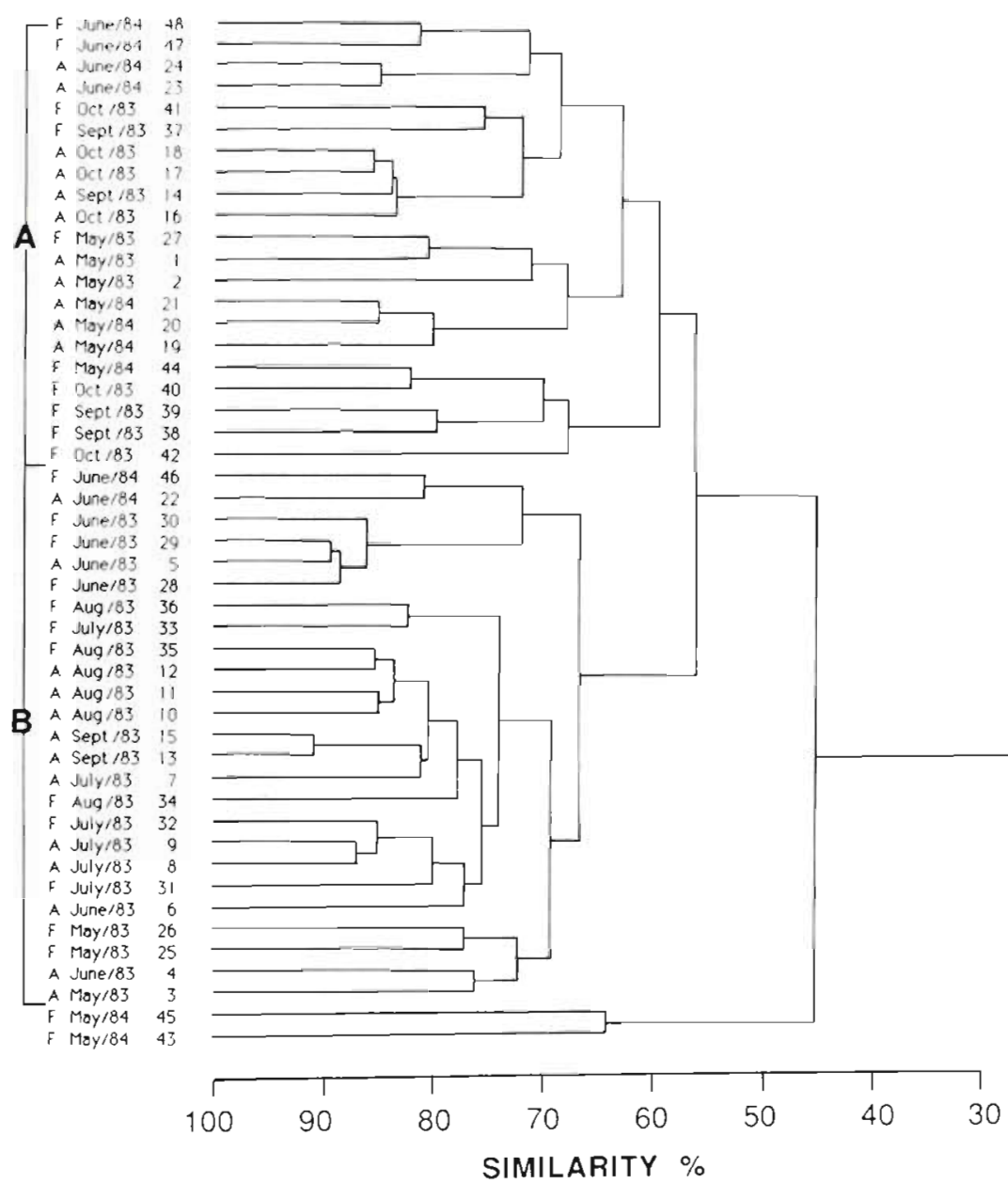

Fig. 13. Ascophyllum nodosum and Fucus vesiculosus. Dendrogram of percentage similarity (Bray-Curtis measure) of faunal composition among 48 samples collected from May through Oct 1983, and May through Jun 1984 at Lower Prospect, Nova Scotia. Total number of samples for each macroalgal species is 24 . Two main clusters $(A, B)$ are delineated at approximately the $56 \%$ similarity level

$3.0 \mathrm{C}^{\circ}$ cooler in the summer and up to $2.0 \mathrm{C}^{\circ}$ warmer in the winter than air temperatures. Epifaunal species such as the amphipod Hyale nilssoni may migrate into the mat when exposed at low tide (McBane \& Croker 1983). Smaller, less motile taxa generally are associated with epiphytic algae which retain large amounts of water when exposed at low tide.

Retention of sediments by macroalgae may also influence species composition and abundance of epifauna in some areas (Dahl 1948, Wieser 1959, Hicks 1977b, Warwick 1977). Epiphytic algae and surface mucus secretions of macroalgae may trap sediment and detritus (Dahl 1948, Hicks 1980). However, sediment retention on plants in this study was low, presumably because of the low turbidity of the embayment and the coarseness of its sediments (pers. obs.). Small quantities of coarse grain sediments occasionally were present on Ascophyllum nodosum and Fucus vesiculosus after storms.

Seasonal changes in the physiological state of the macroalgae may influence the epifaunal assemblage directly or indirectly by affecting the microbial surface film. Increased phenolic release or sloughing of outer cell layers by Ascophyllum nodosum may limit or reduce certain microflora (Filion-Myklebust \& Norton 1981). Increased mucus secretion during reproductive periods may affect phytal epifauna by trapping sediments or rendering the surface uninhabitable (Hagerman 1966). Abundance and species composition of the epifauna on the subtidal macroalga Sargassum seratifolium in the Sea of Japan was related to growth and annual senesence of the plant fronds (Mukai 1971 , Kito 1977). Gunnill (1983) reports that epifauna are in low abundance on Pelvetia fastigiata during the winter reproductive period of the alga, although this may be due to environmental factors rather than algal physiological state. In Nova Scotia, epifaunal abundance increases during the reproductive period of $A$. nodosum (Apr to Jun) but decreases during the reproductive period of Fucus vesiculosus (Sep). Changes in the reproductive condition of macroalgae may affect only those epifauna which dwell on the surfaces of the macroalgae.

Comparisons of Bray-Curtis similarities between samples of Ascophyllum nodosum and Fucus vesiculosus indicate a stronger tendency for samples to 


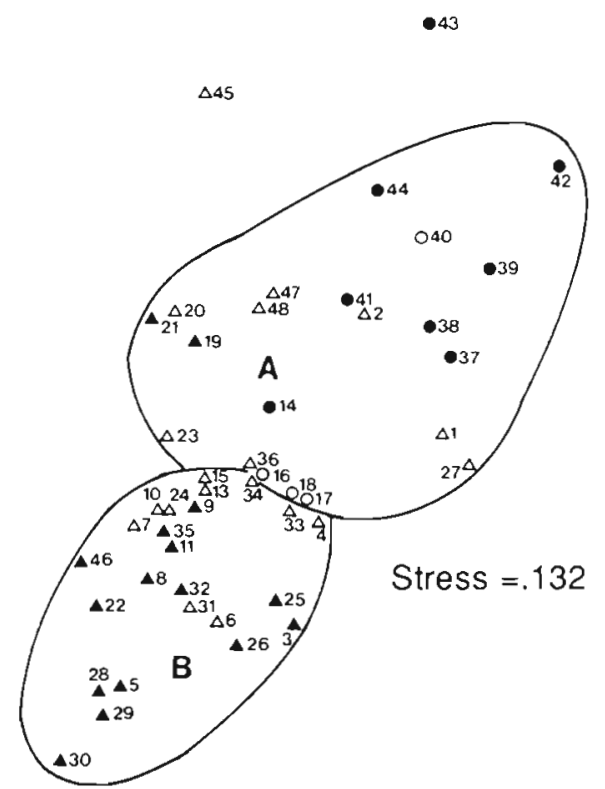

Fig. 14. Ascophyllum nodosum and Fucus vesiculosus. Ordination by multidimensional scaling of 48 samples collected from May through Oct 1983, and May through Jun 1984 at Lower Prospect, Nova Scotia. Total number of samples for each macroalgal species is 24 . Two clusters (A, B) of samples are delineated visually based on the dendrogram in Fig. 13. Symbols indicate different levels of epiphytic algal biomass ( $\mathrm{g}$ dry weight $\mathrm{m}^{-2}$ macroalgal surface) in samples: no symbol, $0 \mathrm{~g} \mathrm{~m}^{-2} ;(0)<0.1 \mathrm{~g} \mathrm{~m}^{-2} ;(\bullet) \geq 0.1,<1.0 \mathrm{~g} \mathrm{~m}^{-2} ;(\Delta) \geq 1.0$, $<10.0 \mathrm{~g} \mathrm{~m}^{-2} ;(\Lambda) \geq 10.0,<100.0 \mathrm{~g} \mathrm{~m}^{-2}$

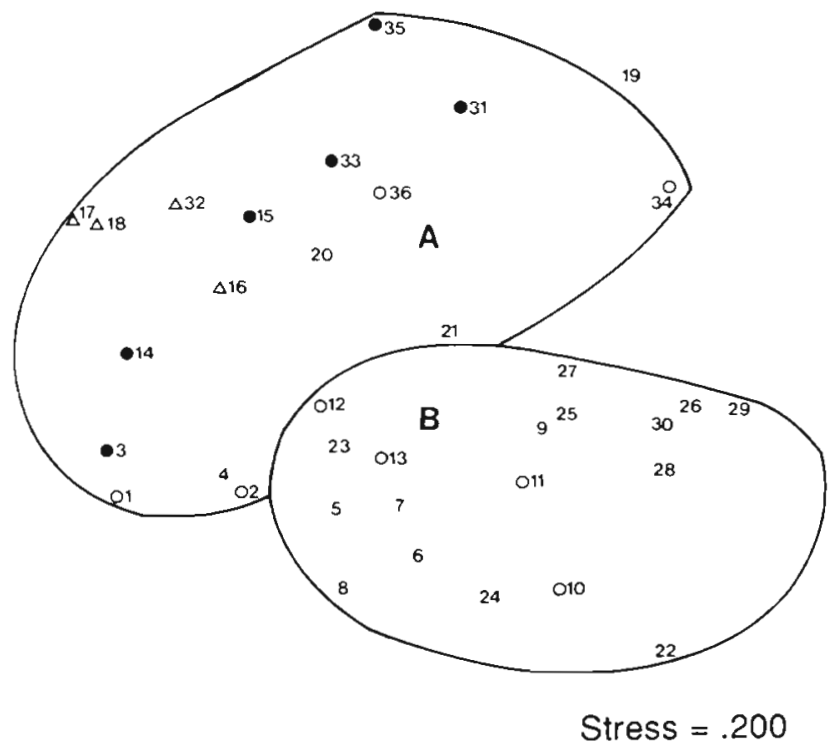

Fig. 16. Ascophyllum nodosum and Fucus vesiculosus. Ordination by multidimensional scaling of 36 samples collected from Nov 1983 to Apr 1984 at Lower Prospect, Nova Scotia. Total number of samples for each macroalgal species is 18 . Two clusters (A, B) of samples are delineated visually based on the dendrogram in Fig. 14. Symbols indicate different levels of epiphytic algal biomass ( $g$ dry weight $\mathrm{m}^{-2}$ macroalgal surface) in samples: no symbol, $0 \mathrm{~g} \mathrm{~m}^{-2}$; (O) $<0.1 \mathrm{~g} \mathrm{~m}^{-2}$; (•) $\geq 0.1,<1.0 \mathrm{~g} \mathrm{~m}^{-2} ;(\Delta) \geq 1.0,<10.0 \mathrm{~g} \mathrm{~m}^{-2} ;(\Delta) \geq 10.0$, $<100.0 \mathrm{~g} \mathrm{~m}^{-2}$

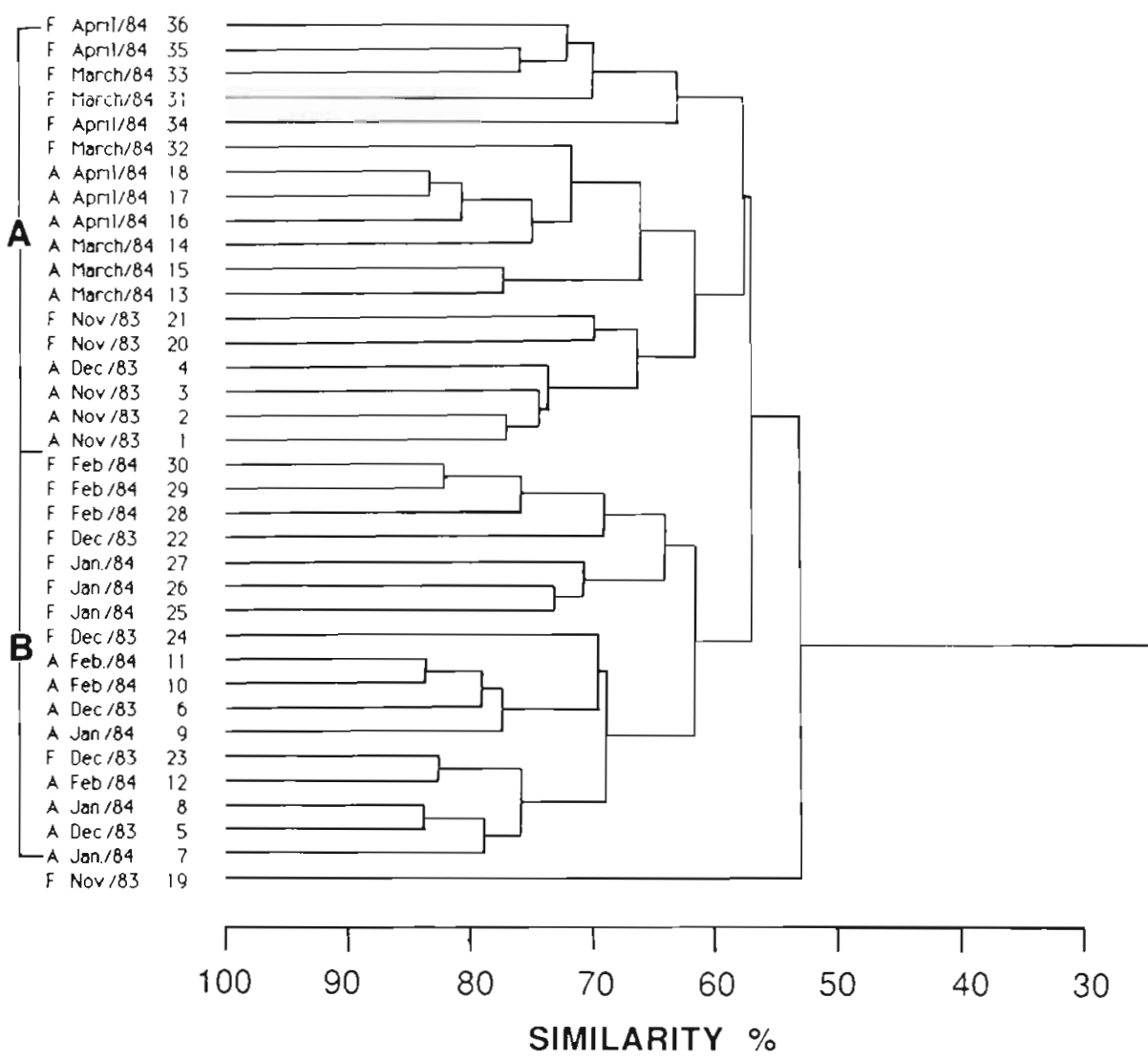

Fig. 15. Ascophyllum nodosum and Fucus vesiculosus. Dendrogram of percentage similarity (Bray-Curtis measure) of faunal composition among 36 samples collected from Nov 1983 to Apr 1984 at Lower Prospect, Nova Scotia. Total number of samples for each macroalgal species is 18 . Two main clusters (A, B) are delineated at approximately the $57 \%$ similarity level 
Appendix 1. Ascophyllum nodosum. Mean density and standard error (in parentheses) of epifauna (individuals $\mathrm{m}^{-2}$ of macroalgal surface) at Lower Prospect, Nova Scotia. Sample size is 3

\begin{tabular}{|c|c|c|c|c|c|c|c|c|c|c|c|c|}
\hline Taxa & & May & & une & & uly & & igust & Septe & ember & October & November \\
\hline Foraminifera & 3 & (3) & 69 & (57) & 454 & $(170)$ & 239 & $(37)$ & 308 & (19) & $429(192)$ & $298(110)$ \\
\hline Turbellaria & 476 & $(424)$ & 1325 & $(724)$ & 14877 & $(8918)$ & 9056 & $(2787)$ & 6662 & (2115) & $2673(854)$ & 413 (239) \\
\hline Unidentified & 468 & $(428)$ & 1311 & $(727)$ & 14848 & (8898) & 8965 & $(2742)$ & 6553 & (2139) & $2649(851)$ & $340(183)$ \\
\hline Notoplana atomata & 8 & (4) & 14 & (4) & 29 & (21) & 91 & $(46)$ & 109 & $(24)$ & $25(10)$ & $74(57)$ \\
\hline Nemertinea & 1 & (1) & 1 & (1) & 15 & (3) & 50 & $(5)$ & 14 & (4) & $6(1)$ & 0 \\
\hline Nematoda & 25773 & $(21603)$ & 62465 & $(36674)$ & 41772 & $(16011)$ & 16371 & $(5738)$ & 4339 & $(1454)$ & $2784(920)$ & $247(70)$ \\
\hline Annelida & 166 & $(70)$ & 366 & (283) & 1257 & $(650)$ & 261 & (81) & 242 & $(58)$ & $70(38)$ & $26(17)$ \\
\hline Lumbricillus lineatus & 166 & $(70)$ & 296 & $(245)$ & 1205 & (619) & 229 & (64) & 212 & $(70)$ & $57(38)$ & $20(15)$ \\
\hline Fabricia sabella & 0 & & 31 & $(43)$ & 47 & (29) & 31 & (16) & 35 & (29) & $11(6)$ & $3(3)$ \\
\hline Spirorbis borealis & 0 & & 0 & & 4 & (4) & 0 & & 0 & & $2(2)$ & $2(2)$ \\
\hline Streptosyllis vanans & 0. & & 0 & & 1 & (1) & & (1) & 1 & (1) & 0 & 0 \\
\hline Unidentified polychaete & 0 & & 0 & & 0 & & 0 & & 0 & & 0 & 0 \\
\hline Gastropoda & 35 & $(20)$ & 164 & $(120)$ & 120 & (74) & 69 & $(37)$ & 58 & (12) & $47(13)$ & $12(11)$ \\
\hline Skeneopsis planorbis & 0 & & 103 & (103) & 9 & (9) & & (1) & 11 & (7) & $3(2)$ & 0 \\
\hline Lacuna vincta & 0 & & 2 & (1) & 3 & (2) & & (2) & 0 & & $5(3)$ & $1(1)$ \\
\hline Littorina Littorea & 0 & & 0 & & 0 & & 0 & & 0 & & 0 & 0 \\
\hline Littorina obtusata & 35 & $(20)$ & 59 & (25) & 108 & $(66)$ & 64 & $(35)$ & 48 & (14) & $39(9)$ & $11(11)$ \\
\hline Misc. gastropod & 0 & & 0 & & 0 & & 0 & & 0 & & 0 & 0 \\
\hline Bivalvia & 22 & (16) & 87 & $(82)$ & 862 & $(309)$ & 98 & $(3 x)$ & 153 & (95) & $94(14)$ & $6(5)$ \\
\hline Mytilus edulis & 22 & (16) & 87 & (82) & 862 & (309) & 97 & (31) & 151 & (96) & $55(21)$ & $6(5)$ \\
\hline Unidentified spat & 0 & & 0 & & 0 & & 0 & & 2 & (1) & $39(30)$ & 0 \\
\hline Halacaridae & 3020 & $(1395)$ & 12540 & $(9484)$ & 21191 & $(3188)$ & 14145 & $(1976)$ & 5573 & $(1902)$ & $3797(197)$ & $897(518)$ \\
\hline Rhombognathides seahami & 2958 & (1357) & 11461 & $(8474)$ & 21039 & (3154) & 13935 & $(1908)$ & 5465 & $\{1912\}$ & $3780(195)$ & 896 (518) \\
\hline Halacarellus spp. & 61 & $(40)$ & 1079 & (1014) & 152 & (43) & 210 & $(81)$ & 108 & (12) & $16(4)$ & $2(2)$ \\
\hline Ostracoda & 3 & (3) & 0 & & 0 & & 0 & & 6 & (6) & $6(3)$ & 0 \\
\hline Harpacticoida & 3533 & (2669) & 55173 & (34 969) & 43919 & (5552) & 37114 & $(4674)$ & 9827 & $(2881)$ & $3743(1580)$ & $567(142)$ \\
\hline Family Ectinosomatidae & 65 & (51) & 77 & $(54)$ & 0 & & 0 & & 0 & & $30(4)$ & 0 \\
\hline Microsetella norvegica & 65 & (51) & 77 & (54) & 0 & & 0 & & 0 & & $30(4)$ & 0 \\
\hline Family Harpacticidae & 297 & $(290)$ & $83 ?$ & $(824)$ & 13 & (12) & 115 & (89) & 0 & & $27(7)$ & $2(1)$ \\
\hline Harpacticus sp. 1 & 41 & (41) & 0 & & 12 & (12) & 11 & (11) & 0 & & $7(5)$ & $1(1)$ \\
\hline Harpacticus sp. 2 & 223 & (217) & 837 & $(824)$ & 1 & (1) & 104 & (78) & 0 & & $20(11)$ & $2(2)$ \\
\hline Harpacticus sp. 3 & 19 & (17) & 0 & & 0 & & 0 & & 0 & & 0 & 0 \\
\hline Zaus abbreviatus & 14 & (14) & 0 & & 0 & & 0 & & 0 & & 0 & 0 \\
\hline Family Tisbidae & 14 & (14) & 25 & (25) & 778 & $(536)$ & 97 & $(66)$ & 124 & $(20)$ & $490(286)$ & $72(12)$ \\
\hline Tisbe spp. & 14 & (14) & 25 & (25) & 788 & $(536)$ & 97 & (66) & 124 & $(20)$ & $490(286)$ & $72(12)$ \\
\hline Family Thalestridae & 180 & (179) & 1081 & (705) & 26 & (26) & 18 & (18) & 67 & (39) & $92(69)$ & $10(5)$ \\
\hline Thalestris purpurea & 41 & (41) & 202 & $(202)$ & 1 & (1) & 18 & (18) & 67 & (39) & 92 (69) & $10(5)$ \\
\hline Thalestris gibba & 0 & & 0 & & 0 & & 0 & & 0 & & 0 & 0 \\
\hline Parathalestris sp. & 1 & (1) & 0 & & 0 & & 0 & & 0 & & 0 & 0 \\
\hline Diarthrodes major & 138 & $(138)$ & 879 & (503) & 25 & $(25)$ & 0 & & 0 & & 0 & 0 \\
\hline Family Parastenhelidae & 0 & & 485 & (485) & 169 & (93) & 445 & (351) & 583 & (54) & $212(46)$ & $22(14)$ \\
\hline Parastenbelia spinosa & 0 & & 485 & $(485)$ & 169 & (93) & 445 & (351) & 583 & (54) & $212(46)$ & 22 (14) \\
\hline Family Diosaccidae & 6 & $(6)$ & 1051 & $(1020)$ & 25 & (25) & 111 & $(47)$ & 220 & (141) & $89(50)$ & 0 \\
\hline Amphiascopsis sp. & 6 & (6) & 1051 & $(1020)$ & 25 & (25) & 111 & $(47)$ & 220 & $(141)$ & $89(50)$ & 0 \\
\hline Family Ameiridae & 43 & (34) & 416 & $(277)$ & 410 & $(300)$ & 615 & (393) & 1234 & $(223)$ & $589(333)$ & 295 (111) \\
\hline Nitocra typica & 43 & (34) & 416 & $(277)$ & 410 & $(300)$ & 615 & (393) & 1234 & (223) & $589(333)$ & 295 (111) \\
\hline Family Canthocamptidae & 1264 & $(795)$ & 5448 & $(2771)$ & 19785 & (1448) & 18929 & (6699) & 4110 & (1523) & $598(175)$ & $141(36)$ \\
\hline Mesochra sp. 1 & 72 & $(72)$ & 0 & & 159 & $(32)$ & 346 & $(260)$ & 427 & (69) & $189(48)$ & $129(41)$ \\
\hline Mesochra sp. 2 & 1193 & (833) & 5448 & $(2771)$ & 19625 & $(1462)$ & 18583 & $(6490)$ & 3686 & (1567) & $408(156)$ & $12(6)$ \\
\hline Family Laophontidae & 1163 & (1387) & 45710 & $(28974)$ & 22713 & $(5398)$ & 16784 & $(4738)$ & 3462 & (1483) & 1521 & $25(13)$ \\
\hline Pseudonychocamptus koreni & 3 & (3) & 0 & & 0 & & 11 & (11) & 0 & & $53(53)$ & $9(9)$ \\
\hline $\begin{array}{l}\text { Heterolaophonte discophora } \\
\text { (adults only) }\end{array}$ & 373 & $(316)$ & 3755 & $(1713)$ & 241 & (134) & 171 & $(170)$ & 62 & $(61)$ & 0 & 0 \\
\hline $\begin{array}{l}\text { Heterolaophonte spp. } \\
\text { (adults only) }\end{array}$ & 743 & $(650)$ & 12756 & $(9040)$ & 10066 & $(871)$ & 5635 & $(1624)$ & 2188 & $(2188)$ & $325(72)$ & $9(4)$ \\
\hline $\begin{array}{l}\text { Heterolaophonte spp. } \\
\text { (juveniles only) }\end{array}$ & 545 & $(423)$ & 29199 & $(18275)$ & 12407 & (4973) & 10966 & (3098) & 1213 & $(484)$ & $1143(411)$ & $7(4)$ \\
\hline Other harpacticoids & 0 & & 42 & $(42)$ & 0 & & 0 & & 25 & (14) & $96(85)$ & $2(2)$ \\
\hline Harpacticoid naupli & 12394 & $(10599)$ & 51195 & $(33020)$ & 51421 & $(35789)$ & 53102 & $(3107)$ & 12417 & $(3700)$ & $5496 \quad(2139)$ & $305(99)$ \\
\hline Centropages typicus & 0 & & 0 & & 0 & & 0 & & 20 & (8) & $3(1)$ & 0 \\
\hline Isopoda & 3 & (1) & 38 & (34) & 118 & $(104)$ & 20 & $(4)$ & 81 & (37) & $24(5)$ & $1(1)$ \\
\hline Jaera marina & 1 & (1) & 19 & (15) & 110 & (103) & 13 & (6) & 72 & (36) & $16(4)$ & 0 \\
\hline Idotea baltica & 2 & (2) & 7 & (7) & 8 & (3) & 7 & (4) & 9 & (2) & $9(1)$ & 1 (1) \\
\hline Idotea phosphorea & 0 & & 12 & (12) & 0 & & 0 & & 0 & & 0 & 0 \\
\hline Amphipoda & 84 & $(76)$ & 567 & $(291)$ & 843 & (431) & 39 & (12) & 28 & $(6)$ & $55(24)$ & $1(1)$ \\
\hline Amphitoe rubncata & 1 & (1) & 14 & (11) & 22 & (8) & & $(2)$ & 24 & (7) & $48 \quad(25)$ & $1(1)$ \\
\hline Callopius laeviusculus & 0 & & 0 & & 3 & (3) & & (4) & 0 & & 0 & 0 \\
\hline Chaetogammarus finmarchicus & 0 & & 1 & (1) & 0 & & 0 & & & (1) & 0 & 0 \\
\hline Gammarellus angulosus & 0 & & 0 & & 0 & & 0 & & 0 & & 0 & 0 \\
\hline Gammarus oceanicus & 1 & (1) & 1 & (1) & 10 & (9) & & (1) & 0 & & 0 & 0 \\
\hline Hyale nilssoni & 82 & (75) & 547 & $(277)$ & 805 & (413) & 25 & (9) & & (1) & $1(1)$ & 0 \\
\hline Jassa falcata & 0 & & 40 & (3) & 3 & (2) & 0 & & & (2) & $6(4)$ & 0 \\
\hline Diptera (larvae) & 563 & $(417)$ & 13285 & (9830) & 3725 & $(315)$ & 2392 & $(635)$ & 427 & $(157)$ & $198(30)$ & $6(4)$ \\
\hline Total & 46076 & $(37233)$ & 197190 & $(125342)$ & 180574 & (53308) & 132957 & $(7381)$ & 40154 & $(11001)$ & $19481 \quad(4804)$ & $2779(688)$ \\
\hline
\end{tabular}


Appendix 1 (continued)

\begin{tabular}{|c|c|c|c|c|c|c|c|}
\hline Taxa & December & January & February & March & April & May & June \\
\hline Foraminifera & $72(12)$ & 66 (21) & $36(16)$ & $23(9)$ & $33(8)$ & $506(139)$ & $624(778)$ \\
\hline Turbellaria & $128(23)$ & $15(11)$ & $35 \quad 12\}$ & $68(28)$ & $18(7)$ & $45(31)$ & $850(423)$ \\
\hline Unidentufied & $127(22)$ & $15(11)$ & $35(12)$ & 65 (28) & $17(6)$ & 42 (32) & $833(427)$ \\
\hline Notoplana atomata & 1 (1) & 0 & $1[1]$ & 3 (1) & $1(1)$ & $3(2)$ & $17(9)$ \\
\hline Nemertinea & 0 & 0 & 0 & $1(1)$ & 0 & 0 & $16(3)$ \\
\hline Nematoda & $100(35)$ & $77(26)$ & $46\{20\}$ & $157(61)$ & $1425(632)$ & $23925 \quad(5775)$ & $17117(12069)$ \\
\hline Annelida & $4(3)$ & $12(10)$ & 7 (5) & 22 (9) & $1(1)$ & 34 (19) & $658(525)$ \\
\hline Lumbricllus lineatus & $3(2)$ & 1 (1) & 0 & $21(8)$ & 1 (1) & 34 (19) & $226(131)$ \\
\hline Fabricia sabella & 0 & $10(10)$ & $6(5)$ & $2(2)$ & 0 & 0 & $418(407)$ \\
\hline Spirorbis borealis & 0 & 0 & 0 & 0 & 0 & 0 & $1(1)$ \\
\hline Streptosylils vanans & $1(1)$ & $1(1)$ & $1(1)$ & 0 & 0 & 0 & 0 \\
\hline Unidentified polychaete & 0 & 0 & 0 & 0 & 0 & 0 & 0 \\
\hline Gastropoda & $1(1)$ & 1 (1) & 0 & $6(2)$ & 0 & $4(1)$ & $76(62)$ \\
\hline Skeneopsis planorbis & 0 & 0 & 0 & 0 & 0 & 0 & $1(1)$ \\
\hline Lacuna vincta & $1(1)$ & 0 & 0 & 0 & 0 & $1(1)$ & 0 \\
\hline Littorina littorea & 0 & 0 & 0 & 0 & 0 & 0 & 0 \\
\hline Littorina obtusata & 0 & $1(1)$ & 0 & $6(3)$ & 0 & $2(1)$ & $74(61)$ \\
\hline Misc. gastropod & 0 & 0 & 0 & 0 & 0 & 0 & 0 \\
\hline Bivalvia & $7(3)$ & $7(5)$ & $1(1)$ & $6(4)$ & $9(7)$ & 0 & $58(36)$ \\
\hline Mytilus edulis & $7(3)$ & $7(5)$ & $1(1)$ & $6(4)$ & $8(7)$ & 0 & $15(12)$ \\
\hline Unidentified spat & 0 & 0 & 0 & 0 & $1(1)$ & 0 & $43(41)$ \\
\hline Halacandae & $166(52)$ & $61(27)$ & $45(29)$ & $327(266)$ & 556 (129) & $1107(603)$ & $6057(5333)$ \\
\hline Rhombognathides seahamu & $166(52)$ & $61(27)$ & $44(28)$ & $324(263)$ & $547(125)$ & $1090 \quad(592)$ & $5810(5107)$ \\
\hline Halacarellus spp. & 0 & 0 & $1(1)$ & 3 (3) & $9(5)$ & $17(12)$ & $247(226)$ \\
\hline Ostracoda & $2(1)$ & $2(0)$ & $3(1)$ & $1(1)$ & $4(2)$ & $7(7)$ & 0 \\
\hline Harpacticoida & $411(141)$ & $511(209)$ & $127(58)$ & $162(64)$ & $371(62)$ & $3502 \quad(539)$ & $58734(44027)$ \\
\hline Family Ectinosomatidae & $5(3)$ & $5(2)$ & $2(1)$ & 6 (3) & 7 (1) & $29(15)$ & 0 \\
\hline Microselella norvegica & $5(3)$ & $5(2)$ & $2(1)$ & $6(3)$ & $7(1)$ & $29(15)$ & 0 \\
\hline Family Harpacticidae & 7 (5) & $4(1)$ & $10(7)$ & 11 (7) & $73(33)$ & $502(408)$ & 0 \\
\hline Harpacticus sp. 1 & $1(1)$ & $2(0)$ & $2(1)$ & 0 & 0 & 0 & 0 \\
\hline Harpacticus sp. 2 & 0 & 1 (1) & 0 & $7(6)$ & $36 \mid 17)$ & $494 \quad(401)$ & 0 \\
\hline Harpacticus sp. 3 & 0 & 0 & 0 & 0 & 4 (1) & $1(1)$ & 0 \\
\hline Zaus abbreviatus & $6(6)$ & $1(1)$ & $8(8)$ & $4(1)$ & $33(21)$ & $7(7)$ & 0 \\
\hline Family Tisbidae & 111 (59) & $261(97)$ & $53(23)$ & $22(6)$ & 29 (3) & 85 (23) & $886(304)$ \\
\hline Tisbe spp. & $111 \quad(59)$ & $261(97)$ & $53(23)$ & $22(6)$ & $29(3)$ & $85(23)$ & $886(304)$ \\
\hline Family Thalestridae & 2 (1) & $4(3)$ & 1 (1) & $3(2)$ & $12(7)$ & $52(27)$ & 0 \\
\hline Thalestris purpurea & 1 (1) & 0 & 0 & 0 & $4(0)$ & $11(6)$ & 0 \\
\hline Thalestris gibba & $1(1)$ & 0 & 0 & 0 & $3(3)$ & 42 (31) & 0 \\
\hline Parathalestris sp. & 0 & $4(3)$ & $1(1)$ & 0 & 1 (1) & 0 & 0 \\
\hline Diarthrodes major & 0 & 0 & 0 & $3(2)$ & $6(3)$ & 0 & 0 \\
\hline Family Parastenheludae & $6(3)$ & $2(2)$ & $i(1)$ & $4 i 4 j$ & $7(3)$ & 0 & $908(878)$ \\
\hline Parastenhelia spinosa & $6(3)$ & $2(2)$ & $1(1)$ & $4(4)$ & $7(3)$ & 0 & 908 (878) \\
\hline Family Diosaccidae & $13(6)$ & 0 & $1(1)$ & $5(3)$ & $8(3)$ & $38(8)$ & $237(217)$ \\
\hline Amphiascopsis sp. & $13(6)$ & 0 & $1(1)$ & $5(3)$ & $8(3)$ & $38(8)$ & $237(217)$ \\
\hline Family Ameiridae & $117(26)$ & $62(33)$ & $25(7)$ & $31(14)$ & $21(3)$ & $7(7)$ & 380 (229) \\
\hline Nitocra typica & $117 \quad(26)$ & $62(33)$ & $25(7)$ & 31 (14) & $21(3)$ & $7(7)$ & $380 \quad(229)$ \\
\hline Family Canthocamptudae & $85(30)$ & $168(74)$ & $29(16)$ & 59 (33) & $65(7)$ & $1601(263)$ & $35062(24876)$ \\
\hline Mesochra sp. 1 & $60(18)$ & $134(75)$ & $21(8)$ & $18(5)$ & $14\{1\}$ & $50(7)$ & $110(83)$ \\
\hline Mesochra sp. 2 & $25(17)$ & $34(23)$ & $8(8)$ & $41 \quad(32)$ & $51(8)$ & $1551(262)$ & $34952(24932)$ \\
\hline Family Laophontidae & $63(57)$ & $5(5)$ & $4(1)$ & $20(11)$ & $131(44)$ & $1181(268)$ & 21291 (18091) \\
\hline Pseudonychocamptus koreni & $57(52)$ & $5(5)$ & $1(0)$ & $2(2)$ & $1(1)$ & 0 & $13(7)$ \\
\hline $\begin{array}{l}\text { Heterolaophonte discophora } \\
\text { (adults only) }\end{array}$ & 0 & 0 & 0 & $8(6)$ & 49 (12) & $31(9)$ & $801(763)$ \\
\hline $\begin{array}{l}\text { Heterolaophonte spp. } \\
\text { (adults only) }\end{array}$ & 0 & 0 & 2 (1) & $10(5)$ & 80 & $159(93)$ & $16297(13785)$ \\
\hline $\begin{array}{c}\text { Heterolaophonte spp. } \\
\text { (juveniles only) }\end{array}$ & $6(6)$ & 0 & 1 (1) & 0 & $1(1)$ & $991(211)$ & $4180 \quad(3552)$ \\
\hline Other harpacticoids & $2(2)$ & $1(1)$ & $3(2)$ & 1 (1) & $19(7)$ & $7(7)$ & $42(42)$ \\
\hline Harpacticoid nauplii & $111(47)$ & 159 (45) & $110(22)$ & $390(99)$ & $2230(733)$ & $15671(1086)$ & $76074(25806)$ \\
\hline Centropages typicus & 0 & 1 (1) & 0 & 0 & $1(1)$ & 0 & 0 \\
\hline Isopoda & 0 & 0 & 0 & 0 & 0 & $2(2)$ & $11(5)$ \\
\hline Jaera marina & 0 & 0 & 0 & 0 & 0 & $1(1)$ & $9(6)$ \\
\hline Idotea baltica & 0 & 0 & 0 & 0 & 0 & $1(1)$ & $1(1)$ \\
\hline Idotea phosphorea & 0 & 0 & 0 & 0 & 0 & 0 & $1(1)$ \\
\hline Amphipoda & 0 & 0 & 0 & 0 & $1\{1\}$ & $5(2)$ & $65(24)$ \\
\hline Amphitoe rubricata & 0 & 0 & 0 & 0 & 0 & $3(1)$ & $1(1)$ \\
\hline Callopius laeviusculus & 0 & 0 & 0 & 0 & 0 & 0 & 0 \\
\hline Chaetogammarus finmarchicus & 0 & 0 & 0 & 0 & $1(1)$ & 0 & 0 \\
\hline Gammarellus angulosus & 0 & 0 & 0 & 0 & 0 & 0 & 0 \\
\hline Gammarus oceanicus & 0 & 0 & 0 & 0 & 0 & $2(1)$ & $36(26)$ \\
\hline Hyale nilssoni & 0 & 0 & 0 & 0 & 0 & 0 & $27(24)$ \\
\hline Jassa falcata & 0 & 0 & 0 & 0 & 0 & 0 & 1 (1) \\
\hline Diptera (larvae) & 0 & $1(1)$ & 0 & $1(1)$ & $12(6)$ & $35(20)$ & $2561 \quad(2374)$ \\
\hline Total & $1000(261)$ & $913(329)$ & $409(148)$ & 1165 (439) & 4659 (1424) & $44870(5574)$ & $163900(90467)$ \\
\hline
\end{tabular}


Appendix 2. Fucus vesiculosus. Mean density and standard error (in parentheses) of epifauna (individuals $\mathrm{m}^{-2}$ of $\mathrm{macroalgal}$ surface) at Lower Prospect, Nova Scotia. Sample size is 3

\begin{tabular}{|c|c|c|c|c|c|c|c|c|c|c|c|}
\hline Taxa & & Aay & & une & & uly & Aus & gust & September & October & November \\
\hline Foraminifera & 257 & $(179)$ & 159 & $(27)$ & 262 & $(122)$ & 635 & (491) & $12(2)$ & $34(12)$ & $66 \quad(23)$ \\
\hline Turbellaria & 1250 & $(1111)$ & 4177 & $\{741\}$ & 6381 & $(2432)$ & 3954 & (2815) & $232(81)$ & $85(45)$ & $48(30)$ \\
\hline Unidentified & 1248 & $(1110)$ & 4176 & $(742)$ & 6380 & (2433) & 3943 & (2815) & $211(68)$ & $79(45)$ & $47(30)$ \\
\hline Notoplana atomata & 3 & (2) & 1 & $(1)$ & 2 & (2) & 11 & (4) & $20(16)$ & $6(3)$ & $1(1)$ \\
\hline Nemertinea & 2 & (2) & 2 & (2) & 4 & (4) & 30 & (17) & $19(17)$ & $1(1)$ & 0 \\
\hline Nematoda & 50624 & $(22875)$ & 280672 & $(73785)$ & 25198 & $(13048)$ & 8794 & (1565) & 504 (299) & 284 (125) & $107(46)$ \\
\hline Annelida & 212 & $(73)$ & 1205 & $(245)$ & 428 & $(207)$ & 157 & (50) & 91 (43) & $18(8)$ & $4(4)$ \\
\hline Lumbricillus Lneatus & 144 & (38) & 861 & $(347)$ & 404 & (209) & 126 & (20) & $76(48)$ & $5(2)$ & $4(4)$ \\
\hline Fabricia sabella & 62 & (50) & 343 & (133) & 24 & (3) & 30 & (30) & 0 & $3(2)$ & 0 \\
\hline Spirorbis borealis & 4 & (2) & 0 & & 0 & & 0 & & $15(11)$ & $10(8)$ & 0 \\
\hline Streptosyllis varians & 0 & & 0 & & 0 & & 0 & & 0 & 0 & 0 \\
\hline Unidentified polychaete & 2 & (2) & 0 & & 0 & & 0 & & 0 & 0 & 0 \\
\hline Gastropoda & 48 & $(16)$ & 123 & (39) & 124 & (67) & 239 & $(144)$ & $49(8)$ & $43(11)$ & $2(2)$ \\
\hline Skeneopsis planorbis & 12 & (12) & 52 & (45) & 2 & (2) & 7 & (4) & $4(2)$ & 1 (1) & 0 \\
\hline Lacuna vincta & 7 & (5) & 0 & & 2 & (2) & 71 & (58) & 0 & $14(9)$ & 0 \\
\hline Littorina Littorea & 0 & & 4 & $(2)$ & 3 & (2) & 0 & & $1(1)$ & 0 & 0 \\
\hline Littorina obtusata & 27 & $(2)$ & 67 & (39) & 116 & $(70)$ & 162 & (87) & $45(8)$ & $27(11)$ & $2(2)$ \\
\hline Misc. gastropod & 0 & & 0 & & 0 & & 0 & & 0 & 0 & 0 \\
\hline Bivalvia & 25 & (14) & 26 & $(18)$ & 572 & (193) & 549 & $(480)$ & $10(2)$ & $2(1)$ & 1 (1) \\
\hline Mytilus edulis & 25 & (14) & 26 & (18) & 572 & (193) & 549 & $(480)$ & $10(2)$ & $2(1)$ & $1(1)$ \\
\hline Unidentified spat & 0 & & 0 & & 0 & & 0 & & 0 & 1 (1) & 0 \\
\hline Halacaridae & 6601 & $(1336)$ & 44681 & $(9376)$ & 18258 & $(2752)$ & 9071 & (1547) & $2206(314)$ & $1440(370)$ & $171(100)$ \\
\hline Rhombognathides seahami & 6135 & $(1066)$ & 41127 & $(8947)$ & 17993 & $(2748)$ & 8969 & (1492) & $2200(313)$ & $1438(368)$ & $169(98)$ \\
\hline Halacarellus spp. & 463 & $(297)$ & 3554 & (585) & 267 & (45) & 102 & (62) & $6(2)$ & $2(2)$ & $3(2)$ \\
\hline Ostracoda & 80 & $(74)$ & 53 & $(53)$ & 0 & & 0 & & $2(1)$ & 5 (5) & $5(4)$ \\
\hline Harpacticoida & 12032 & $(6597)$ & 244402 & $(37502)$ & 25392 & $(8749)$ & 10726 & $(4340)$ & $1129(612\}$ & $1199(892)$ & 190 \\
\hline Family Ectinosomatidae & 471 & $(225)$ & 37 & $(37)$ & 0 & & 0 & & $39(12)$ & $12(7)$ & 0 \\
\hline Microsetella norvegica & 471 & $(225)$ & 37 & $(37)$ & 0 & & 0 & & $39(19)$ & $12(7)$ & 0 \\
\hline Family Harpacticidae & 669 & (323) & 715 & $(212)$ & 108 & $(94)$ & 256 & $(138)$ & $2(1)$ & $51(24)$ & $9(2)$ \\
\hline Harpacticus sp. 1 & 0 & & 54 & (52) & 0 & & 0 & & 0 & $2(2)$ & $5(3)$ \\
\hline Harpacticus sp. 2 & 610 & $(330)$ & 662 & $(237)$ & 10 & $(10)$ & 256 & $(138)$ & $2(1)$ & $44 \quad(28)$ & $4(1)$ \\
\hline Harpacticus sp. 3 & 52 & $(47)$ & 0 & & 98 & (98) & 0 & & 0 & 0 & 0 \\
\hline Zaus abbreviatus & 7 & (4) & 0 & & 0 & & 0 & & 0 & $4(3)$ & 0 \\
\hline Family Tisbidae & 69 & $\{69\}$ & 0 & & 128 & (79) & 73 & $(73)$ & $87(74)$ & $99(44)$ & $110(52)$ \\
\hline Tisbe spp. & 69 & (69) & 0 & & 128 & (79) & 73 & (73) & $87(74)$ & $99(44)$ & $110(52)$ \\
\hline Family Thalestridae & 1278 & $(1250)$ & 26066 & (7149) & 1558 & $(1084)$ & 31 & (31) & $517(362)$ & $711 \quad(694)$ & $24(22)$ \\
\hline Thalestris purpurea & 73 & $(67)$ & 165 & $(76)$ & 1509 & $(1100)$ & 31 & (31) & $517\{362\}$ & $710(694)$ & $24(22)$ \\
\hline Thalestris gibba & 0 & & 3 & (3) & 0 & & 0 & & 0 & 0 & 0 \\
\hline Parathalestris sp. & 38 & $(33)$ & 0 & & 0 & & 0 & & 0 & 0 & 0 \\
\hline Diarthrodes major & 167 & $(1150)$ & 25897 & (7181) & 49 & $(49)$ & 0 & & 0 & $1(1)$ & 0 \\
\hline Family Parastenheliidae & 105 & (61) & 1458 & $(940)$ & 0 & & 288 & (209) & $6(4)$ & $18(9)$ & $11(5)$ \\
\hline Parastenhelia spinosa & 105 & (61) & 1458 & $(940)$ & 0 & & 288 & (209) & $6(4)$ & $18(9)$ & $11(5)$ \\
\hline Family Diosaccidae & 0 & & 3106 & (351) & 0 & & 138 & (108) & 0 & $6(6)$ & 0 \\
\hline Amphiascopsis sp. & 0 & & 3106 & (351) & 0 & & 138 & $(108)$ & 0 & $6(6)$ & 0 \\
\hline Family Ameiridae & 35 & $(35)$ & 2325 & $(579)$ & 79 & (43) & 223 & $(74)$ & $268(192)$ & $148(81)$ & $3(3)$ \\
\hline Nitocra typica & 35 & $(35)$ & 2325 & $(579)$ & 79 & (43) & 223 & (74) & $268(192)$ & $148(81)$ & $3(3)$ \\
\hline Family Canthocamptidae & 1642 & $(778)$ & 23737 & (7949) & 5454 & (3019) & 1696 & $(875)$ & $119(72)$ & $76(58)$ & $22(7)$ \\
\hline Mesochra sp. 1 & 35 & (35) & 0 & & 0 & & 72 & (41) & $107(79)$ & $44(41)$ & $22(7)$ \\
\hline Mesochra sp. 2 & 1607 & $(775)$ & 23737 & $(7949)$ & 5454 & $(3019)$ & 1624 & $(840)$ & $12(9)$ & $32(17)$ & 0 \\
\hline Family Laophontidae & 7484 & $(4110)$ & 186959 & $(31785)$ & 18065 & $(8223)$ & 8010 & $(3170)$ & $82(43)$ & $74(46)$ & $10(7)$ \\
\hline Pseudonychocamptus koreni & 189 & $(139)$ & 0 & & 0 & & 0 & & 0 & $21(21)$ & 0 \\
\hline $\begin{array}{l}\text { Heterolaophonte discophora } \\
\text { (adults only) }\end{array}$ & 1143 & $(560)$ & 25553 & (2809) & 627 & $(572)$ & 0 & & 0 & 0 & 0 \\
\hline $\begin{array}{l}\text { Heterolaophonte spp. } \\
\text { (adults only) }\end{array}$ & 558 & $(252)$ & 38226 & $(7576)$ & 6857 & $(3069)$ & 2384 & $(508)$ & $65(32)$ & $18(9)$ & $3(2)$ \\
\hline $\begin{array}{l}\text { Heterolaophonte spp. } \\
\text { (juveniles only) }\end{array}$ & 5594 & $(3460)$ & 123180 & $(25290)$ & 10580 & $(5980)$ & 5626 & (2663) & $18(13)$ & $36(19)$ & $7(6)$ \\
\hline Other harpacticoids & 279 & (151) & 53 & (53) & 0 & & 10 & (10) & $10(9)$ & $4(3)$ & 1 (1) \\
\hline Harpacticoid nauplii & 125146 & $(77434)$ & 205587 & $(60013)$ & 10375 & $(2974)$ & 27172 & (9821) & $1983(869)$ & $2650(1608)$ & 315 (157) \\
\hline Centropages typicus & 0 & & 0 & & 0 & & 0 & & $23(9)$ & $1(1)$ & 0 \\
\hline Isopoda & 2 & (2) & 20 & (3) & 18 & $(8)$ & 12 & (5) & $16(8)$ & 27 (19) & $1(1)$ \\
\hline Jaera marina & 0 & & 2 & (2) & 9 & (3) & 3 & (2) & $11(7)$ & $22(18)$ & $1(1)$ \\
\hline Idotea baltica & 2 & $(2)$ & 6 & (3) & 9 & (9) & 9 & (4) & $6(6)$ & $5(2)$ & 0 \\
\hline Idotea phosphorea & 0 & & 12 & (7) & 0 & & 0 & & 0 & 0 & 0 \\
\hline Amphipoda & 100 & $(48)$ & 1174 & (469) & 479 & $(283)$ & 341 & $(272)$ & $4(3)$ & $7(1)$ & $1(1)$ \\
\hline Amphitoe rubricata & 47 & (24) & 109 & $(80)$ & 32 & (19) & 10 & (4) & $2(1)$ & 0 & 0 \\
\hline Calliopius Iaeviusculus & 0 & & 0 & & 0 & & 56 & (30) & 0 & 0 & 0 \\
\hline Chaetogammarus finmarchicus & 2 & $(2)$ & 0 & & 0 & & 0 & & 0 & 0 & 0 \\
\hline Gammarus oceanicus & 1 & (1) & 0 & & 4 & (4) & 2 & (2) & 0 & 0 & 0 \\
\hline Hyale nilssoni & 49 & $(26)$ & 1055 & (489) & 443 & $(260)$ & 272 & (263) & $2(2)$ & $4(2)$ & 0 \\
\hline Jassa falcata & 3 & (2) & 10 & (7) & 0 & & 1 & (1) & 0 & $3(2)$ & $1\{1\}$ \\
\hline Diptera (larvae) & 1064 & $(485)$ & 35473 & $(16180)$ & 1703 & $(585)$ & 565 & $(212)$ & $21(7)$ & $5(5)$ & $2(2)$ \\
\hline Total & 197386 & $(107762)$ & 817753 & $(190676)$ & 89195 & (25 315) & 62246 & (20028) & $6302(2091)$ & $5799(2981)$ & $913(383)$ \\
\hline
\end{tabular}


Appendix 2 (continued)

\begin{tabular}{|c|c|c|c|c|c|c|c|c|}
\hline Taxa & December & January & February & March & April & May & & une \\
\hline Foramınutera & $52(24)$ & $263(118)$ & $25(8)$ & $135(116)$ & $100(56)$ & $233(67)$ & 5337 & $(1286)$ \\
\hline Turbellana & $14(8)$ & $1(1)$ & $10(4)$ & $3(2)$ & $2(1)$ & $8(7)$ & 324 & $(277)$ \\
\hline Unidentified & $14(8)$ & 1 (1) & $10\lfloor 4\rfloor$ & 2 (1) & $2(1)$ & $7(5)$ & 313 & (282) \\
\hline Notoplana atomata & 0 & 0 & 0 & 1 (1) & 0 & $1(1)$ & 11 & (6) \\
\hline Nemertinea & 0 & 0 & 0 & 0 & 0 & 1 (1) & 28 & (11) \\
\hline Nematoda & $107(28)$ & $114(34)$ & $87(22)$ & 50 (11) & $49(20)$ & $1117(641)$ & 3931 & $(3534)$ \\
\hline Annelida & $3(0)$ & 1 (1) & 0 & 0 & $2(2)$ & 0 & 937 & (368) \\
\hline Lumbricillus lineatus & 1 (1) & 0 & 0 & 0 & 2 (2) & 0 & 404 & (171) \\
\hline Fabricia sabella & 1 (1) & $1(1)$ & 0 & 0 & 0 & 0 & & (6) \\
\hline Spirorbis borealis & 1 (1) & 0 & 0 & 0 & 0 & 0 & 526 & (502) \\
\hline Streptosylls vanians & 0 & 0 & 0 & 0 & 0 & 0 & 0 & \\
\hline Unidentified polychaete & 0 & 0 & 0 & 0 & 0 & 0 & 0 & \\
\hline Gastropoda & $1(1)$ & 0 & 0 & $9(6)$ & $2(2)$ & $12(10)$ & 296 & (249) \\
\hline Skeneopsis planorbis & 0 & 0 & 0 & 0 & 0 & 0 & 0 & \\
\hline Lacuna vincta & 0 & 0 & 0 & $2(2)$ & 0 & $2(2)$ & 0 & \\
\hline Littorina littorea & 0 & 0 & 0 & 1 (1) & 0 & 0 & & (2) \\
\hline Littorina obtusata & $1(1)$ & 0 & 0 & $6(4)$ & $2(2)$ & $9(8)$ & 293 & (249) \\
\hline Misc. gastropod & 0 & 0 & 0 & 0 & 0 & 0 & & (1) \\
\hline Bivalvia & $9(5)$ & 0 & 0 & 0 & $1(1)$ & $4(4)$ & 110 & (93) \\
\hline Mytilus edulis & $9(5)$ & 0 & 0 & 0 & 1 (1) & 3 (3) & 12 & (7) \\
\hline Undentified spat & 0 & 0 & 0 & 0 & 0 & 1 (1) & 98 & (98) \\
\hline Halacaridae & $56(28)$ & $94(50)$ & $19(5)$ & $416(159)$ & $126(7)$ & $535(257)$ & 10593 & (6631) \\
\hline Rhombognathides seahami & $56(28)$ & $93(50)$ & 19 (5) & $415 \quad(159)$ & $126(7)$ & $525(257)$ & 10493 & (6578) \\
\hline Halacarellus spp. & 0 & $1(1)$ & 0 & 1 (1) & 0 & $10(2)$ & 100 & (53) \\
\hline Ostracoda & $2(1)$ & 3 (3) & 0 & 1 (1) & $14(12)$ & $4(4)$ & 16 & (16) \\
\hline Harpacticoida & $132(57)$ & $258(58)$ & $107(47)$ & $169(70)$ & $72(31)$ & $1351(1093)$ & 22525 & $(20096)$ \\
\hline Family Ectinosomatidae & 1 (1) & 0 & 0 & $3(2)$ & $2(1)$ & 1 (1) & 0 & \\
\hline Microsetella norvegica & 1 (1) & 0 & 0 & $3(2)$ & 2 (1) & 1 (1) & 0 & \\
\hline Family Harpacticidae & 1. (1) & $20(15)$ & $1(1)$ & $26(8)$ & 29 (14) & $1146(1023)$ & 513 & (499) \\
\hline Harpacticus sp. 1 & 1 (1) & $4(4)$ & 0 & 0 & 1 (1) & 0 & 33 & (33) \\
\hline Harpacticus sp. 2 & 0 & 0 & 0 & $18(12)$ & $12(10)$ & $1146(1023)$ & 0 & \\
\hline Harpacticus sp. 3 & 0 & 0 & 0 & 0 & $2(1)$ & 0 & 0 & \\
\hline Zaus abbreviatis & 0 & $19(10)$ & $1(1)$ & $9(4)$ & $15(9)$ & 0 & 481 & $(467)$ \\
\hline Family Tisbidae & $53(28)$ & $204(49)$ & $96(42)$ & $87(39)$ & $20(16)$ & $34(29)$ & 681 & $(372)$ \\
\hline Tisbe spp. & $53(28)$ & $204(49)$ & $96(42)$ & $87(39)$ & $20(16)$ & $34(29)$ & 681 & $(372)$ \\
\hline Family Thalestridae & 7 (2) & $1(1)$ & 0 & 5 (2) & $10(2)$ & $2(1)$ & 97 & (75) \\
\hline Thalestris purpurea & 0 & 0 & 0 & $2(0)$ & 9 (2) & 1 (1) & 81 & (59) \\
\hline Thalestris gibba & 0 & 0 & 0 & 0 & 1 (1) & 0 & 0 & \\
\hline Parathalestris sp. & $7(2)$ & $1(1)$ & 0 & 0 & 0 & 0 & 0 & \\
\hline Diarthrodes major & 0 & 0 & 0 & $3(2)$ & 0 & $1(1)$ & 16 & (16) \\
\hline Famuly Parastenheiudae & $\hat{y}$ iôj & $\hat{o}(\hat{0})$ & 0 & 0 & 0 & $7(5)$ & 1319 & (1316) \\
\hline Parastenhelia spinosa & $9(6)$ & $8(6)$ & 0 & 0 & 0 & $7(5)$ & 1319 & (1316) \\
\hline Family Diosaccidae & $9(5)$ & 0 & 0 & $2(1)$ & $1(1)$ & $6(6)$ & 223 & (181) \\
\hline Amphuascopsis sp. & $9(5)$ & 0 & 0 & 2 (1) & 1 (1) & $6(6)$ & 223 & (181) \\
\hline Family Ameiridae & $32(5)$ & $8(8)$ & $4(4)$ & $11(10)$ & $3(3)$ & 18 (1) & 878 & (413) \\
\hline Nitocra typica & $32(5)$ & $8(8)$ & 4 (4) & $11(10)$ & $3(3)$ & $18(1)$ & 878 & (413) \\
\hline Family Canthocamptidae & $16(15)$ & $9(3)$ & $5(5)$ & $10(3)$ & $3(2)$ & $52(33)$ & 8124 & $(7984)$ \\
\hline Mesochra sp. 1 & $2(2)$ & $9(3)$ & $2(2)$ & $3(2)$ & 0 & $3(2)$ & 68 & (40) \\
\hline Mesochra sp. 2 & $14(12)$ & 0 & 3 (3) & 7 (1) & $3(2)$ & $49(35)$ & 8056 & $(8018)$ \\
\hline Famly Laophontidae & $2(1)$ & $4(4)$ & 1 (1) & $24(21)$ & 3 (3) & $85(43)$ & 10605 & $(10109)$ \\
\hline Pseudonychocamptus koreni & 0 & 0 & 1 (1) & $15(13)$ & 0 & 0 & 40 & (28) \\
\hline $\begin{array}{l}\text { Heterolaophonte discophora } \\
\text { (adults only) }\end{array}$ & 0 & 0 & 0 & $4(3)$ & 1 (1) & $1(1)$ & 285 & (282) \\
\hline $\begin{array}{l}\text { Heterolaophonte spp. } \\
\text { (adults only) }\end{array}$ & $1(1)$ & 0 & 0 & $5(4)$ & $2(2)$ & $41(22)$ & 8720 & (8382) \\
\hline $\begin{array}{l}\text { Heterolaophonte spp. } \\
\text { (juveniles only) }\end{array}$ & $1(1)$ & $4(4)$ & 0 & $1(1)$ & 0 & $43(23)$ & 1561 & $(1465)$ \\
\hline Other harpacticoids & $2(0)$ & $1(1)$ & $1(1)$ & $1(1)$ & $2(0)$ & 0 & 85 & (79) \\
\hline Harpacticoid nauplii & $61(26)$ & $358(69)$ & 196 & $558(142)$ & $583(156)$ & $1560(880)$ & 22764 & $(14426)$ \\
\hline Centropages typicus & 0 & 0 & 0 & 0 & $2(1)$ & 0 & 0 & \\
\hline Isopoda & 0 & 0 & 0 & $2(2)$ & 0 & $2(2)$ & 19 & (6) \\
\hline Jaera manna & 0 & 0 & 0 & $2(2)$ & 0 & 0 & 19 & (6) \\
\hline Idotea baltica & 0 & 0 & 0 & 0 & 0 & $2(2)$ & 0 & \\
\hline Idotea phosphorea & 0 & 0 & 0 & 0 & 0 & 0 & 0 & \\
\hline Amphipoda & 0 & $1(1)$ & 0 & 1 (1) & $1(1)$ & $2(1)$ & 310 & (291) \\
\hline Amphitoe rubncata & 0 & 0 & 0 & 0 & 0 & 0 & & (1) \\
\hline Calliopius laeviusculus & 0 & 0 & 0 & 0 & 0 & 0 & 0 & \\
\hline Chaetogammarus finmarchicus & 0 & 0 & 0 & 0 & $1(1)$ & 0 & 0 & \\
\hline $\begin{array}{l}\text { Gammarus oceanicus } \\
\text { als }\end{array}$ & 0 & 0 & 0 & 0 & 0 & 0 & 12 & (8) \\
\hline Hyale nilssoni & 0 & $1(1)$ & 0 & 0 & 0 & 0 & 296 & (296) \\
\hline Jassa falcata & 0 & 0 & 0 & $1(1)$ & 0 & $1(1)$ & 0 & \\
\hline Diptera (larvae) & 0 & 0 & 0 & 0 & 0 & i (1) & 1368 & $(1349)$ \\
\hline Total & $436(166)$ & $1095(92)$ & $445(54)$ & 1345 & $951(195)$ & 4829 (2479) & 86560 & $(47118)$ \\
\hline
\end{tabular}


separate according to macroalgal species from November to April, when epiphytic biomass was low, than from May to October, when epiphytic algal biomass was high. A. nodosum and $F$. vesiculosus have different phenologies (A. nodosum consists of numerous slender elliptical stalks, while $F$. vesiculosus has numerous broad thin thalli). These differences may be obscured by epiphytic algae when they are abundant. Since $A$. nodosum and $F$. vesiculosus have a similar epiphytic flora (Sieburth \& Tootle 1981), differences in the composition of epifauna between $A$. nodosum and $F$. vesiculosus may only become apparent when epiphytic algae are sparse or absent.

Acknowledgements. This research was funded by a Natural Sciences and Engineering Research Council Operating Grant to RES. SCJ was supported by a Natural Sciences and Engineering Research Council Postgraduate Scholarship and a Dalhousie University Graduate Scholarship.

\section{LITERATURE CITED}

Bloom, S. A., Santos, S. L., Field, J. G. (1977). A package of computer programs for benthic community analyses. Bull. mar. Sci. 27: 577-580

Box, G. E. P., Hunter, W. G., Hunter, J. S. (1978). Statistics for experimenters. An introduction to design, data analysis, and model building. John Wiley and Sons, New York

Colman, J. (1940). On the faunas inhabiting intertidal seaweeds. J. mar. biol. Ass. U.K. 24: 129-183

Coull, B. C., Creed, E. L., Eskin, R. A., Montagna, P. A., Palmer, M. A., Wells, J. B. J. (1983). Phytal meiofauna from the rocky intertidal at Murrell's Inlet, South Carolina. Trans. Am. microsc. Soc. 102: 380-389

Coull, B. C., Wells, J. B. J. (1983). Refuges from fish predation: experiments with phytal meiofauna from the New Zealand rocky intertidal. Ecology 64: 1599-1609

Dahl, E. (1948). On the smaller Arthropoda of marine algae, especially in the polyhaline waters of the Swedish West Coast. Undersokningar over Oresund 35: 4-193

D'Antonio, C. (1985). Epiphytes on the rocky intertidal red alga Rhodomela larix (Turner) C. Agardh: negative effects on the host and food for herbivores? J. exp. mar. Biol. Ecol. 86: $197-218$

Edgar, G. J. (1983). The ecology of South-east Tasmanian phytal animal communities. II. Seasonal change in plant and animal populations. J. exp. mar. Biol. Ecol. 70: $159-179$

Field, J. G., Clarke, K. R., Warwick, R. M. (1982). A practical strategy for analysing multispecies distribution patterns. Mar. Ecol. Prog. Ser. 8: 37-52

Filion-Myklebust, C., Norton, T A. (1981). Epidermis shedding in the brown seaweed Ascophyllum nodosum (1.) Le Jolis, and its ecological significance. Mar. Biol. Lett. 2: $45-51$

Gunnill, F. C. (1982). Effects of plant size and distribution on the numbers of invertebrate species and individuals inhabiting the brown alga Pelvetia fastigiata. Mar. Biol. 69: $263-280$

Gunnill, F. C. (1983). Seasonal variations in the invertebrate faunas of Pellvetia fastigiata (Fucaceae): effects of plant size and distribution. Mar. Biol. 73: 115-130
Haage, P. (1975). Quantitative investigations of the Baltic Fucus belt macrofauna. 2. Quantitative seasonal fluctuations. Contr. Asko Lab. Univ. Stockholm 9: 1-88

Hagerman, L. (1966). The macro- and microfauna associated with Fucus serratus L., with some ecological remarks. Ophelia 3: 1-43

Hicks, G. R. F. (1977a). Observations on substrate preference of marine phytal harpacticoids (Copepoda). Hydrobiologia 56: 7-9

Hicks, G. R. F. (1977b). Species composition and zoogeography of marine phytal harpacticoid copepods from Cook Strait, and their contribution to total phytal meiofauna. N. Z. Jl mar. Freshwat. Res. 11: 441-469

Hicks, G. R. F. $(1977 \mathrm{c})$. Species associations and seasonal population densities of marine phytal harpacticoid copepods from Cook Strait. N. Z. Jl mar. Freshwat. Res. 11: $621-643$

Hicks, G. R. F. (1980). Structure of phytal harpacticoid copepod assemblages and the influence of habitat complexity and turbidity. J. exp. mar. Biol. Ecol. 44: 157-192

Hicks, G. R. F. (1985). Meiofauna associated with rocky shore algae. In: Moore, P. G., Seed, R. (ed.) The ecology of rocky coasts. Hodder and Stoughton, London, p. 36-56

Kangas, P. (1978). On the quantity of meiofauna among the epiphytes of Fucus vesiculosus in the Askö area, northern Baltic Sea. Contr. Askö Lab. Univ. Stockholm 24: 1-32

Kito, K. (1977). Phytal animals in the Sargassum confusum region in Oshoro Bay, Hokkaido: phenology of harpacticoid copepods. J. Fac. Sci. Hokkaido Univ., Ser. VI, Zool. 20: 691-698

Kruskal, J. B. (1964a). Multidimensional scaling by optimizing goodness of fit to a nonmetric hypothesis. Psychometrika 29: 1-27

Kruskal, J. B. (1964b). Nonmetric multidimensional scaling: a numerical method. Psychometrika 29: 115-129

Lee, J. L., Teitjen, J. H., Garrison, J. R. (1976). Seasonal switching in the nutritional requirements of Nitocra typica a harpacticoid copepod from salt marsh aufwuchs communities. Trans. Am. micros. Soc. 95: 628-637

Maquire, T. O. (1969). Program for Kruskal-Shepard multidimensional scaling. Division of Educational Research Services, Univ. of Alberta, Edmonton

Marcotte, B. M. (1977). The ecology of meiobenthic harpacticoids (Crustacea: Copepoda) in West Lawrencetown, Nova Scotia. Ph. D, thesis, Dalhousie Univ., Halifax

McBane, C. D., Croker, R. A. (1983). Animal-algal relationships of the amphipod Hyale nilsonni (Rathke) in the rocky intertidal. J. Crust. Biol. 3: 592-601

Morley, R. L., Ring, R. A. (1972). The intertidal Chironomidae (Diptera) of British Columbia. II. Life history and population dynamics. Can. Ent. 104: 1099-1121

Mukai, H. (1971). The phytal animals on the thalli of Sargassum serratifolium in the Sargassum region, with reference to their seasonal fluctuations. Mar. Biol. 8: 170-182

Nagel, J. S. (1968). Distribution of the epibiota of macroepibenthic plants. Contr. mar. Sci. 13: 105-144

Ohm, G. (1964). Die Besiedlung der Fucus-Zone der Kieler Bucht und der westlichen Ostsee unter besonderer Berücksichtigung der Mikrofauna. Kieler Meeresforsch. (Sonderh.) 20: 30-64

Pederson, J. B., Capuzzo, J. M. (1984). Energy budget of an omnivorous rocky shore amphipod, Calliopius laeviusculus (Kroyer). J. exp. mar. Biol. Ecol. 76: 277-294

Ray, A. A. (1982). SAS users guide, 5th edn. SAS Institute Inc. Cary, North Carolina

Sieburth, J. McN., Tootle, J. L. (1981). Seasonality of microbial fouling on Ascophyllum nodosum (L.) Lejol., Fucus 
vesiculosus L., Polysiphonia lanosa (L.) Tandy and Chondrus crispus Stackh. J. Phycol. 17: 57-64

Trotter, D. B., Webster, J. M. (1983). Distribution and abundance of marine nematodes on the kelp Macrocystis integrifolia. Mar. Biol. 78: 39-43

Trotter, D. B., Webster, J. M. (1984). Feeding preferences and seasonality of free-living marine nematodes inhabiting the kelp Macrocystis integnifolia. Mar. Ecol. Prog. Ser. 14: 151-157

Underwood, A. J. (1981). Techniques of analysis of variance in experimental marine biology and ecology. Oceanogr. mar. Biol. A. Rev. 19: 513-605
Warwick, R. M. (1977). The structure and seasonal fluctuations of phytal marine nematode associations of the Isles of Scilly. In: Keegan, B. F., O'Ceidigh, P., Boaden, P. J. S. (ed.) Biology of benthic organisms. Proc. 11th. Europ. Mar. Biol. Symp. Pergamon Press, Oxford, p. 577-585

Wieser, W. (1959). Zur Okologie der Fauna mariner Algen mit besonderer Berücksichtigung des Mittelmeeres. Int. Revue ges. Hydrobiol 44: 137-180

Zavodnik, D. (1967). The community of Fucus virsoides (Don). J. Ag. on a rocky shore near Rovinji (Northern Adriatic). Thalassia jugosl. 3: 105-113

This article was presented by Dr. R. J. Conover; it was accepted for printing on February 16, 1987 